This manuscript has been submitted for publication in BASIN RESEARCH. Please note that the manuscript is currently in the peer-review process. Subsequent versions of the manuscript may have slightly modified content. Please feel free to contact any of the authors; we welcome feedback. 


\title{
Syn- to post-rift alluvial basin fill: seismic stratigraphic analysis of Permian-Triassic deposition in the Horda Platform, Norway
}

\author{
Camilla L. Würtzen $^{1} \quad$ ～Johnathon L. Osmond ${ }^{1} \quad$ Jan Inge Faleide ${ }^{1}$ ｜ \\ Johan Petter Nystuen $^{1} \quad$ | Ingrid M. Anell ${ }^{1}$ ～Ivar Midtkandal ${ }^{1}$ \\ 1Department of Geosciences, University of Oslo, P.O. Box 1047, Blindern, N-031 Oslo
}

\section{Correspondence}

Camilla L. Würtzen, University of Oslo, P.O. Box 1047, Blindern, N-031 Oslo

E-mail: c.l.wurtzen@geo.uio.no

Funding information

NCCS

\begin{abstract}
Discrepancies in models of continental rift-basin dynamics and stratigraphic response calls on further investigation on the subject. Geometric- and lithological trends between stages of faulting is studied in the PermianTriassic continental rift succession in the Horda Platform. The Horda Platform occupies the northeastern margin of the North Sea aulacogen where Late Permian-Early Triassic faulting shaped the Caledonian pre-rift landscape into a series of N-S trending half-graben basins, filled by Permian-Triassic strata. A tectonostratigraphic model developed from seismic- and well-data details the Permian-Triassic basin fill and structural basin development. Regional unconformities mark the top and base of the succession, while internally, six depositional sequences are delineated by erosional- and transgressive surfaces. Thickness maps reveal three syn-rift stages, where strain migrated and concentrated in different parts of the developing rift basin, from disconnected faults and scattered depocentres with varying accommodation space hosting deposits of different thicknesses, to fully linked faults bounding half-graben basins with expanded and connected depocentres. The lithology through the syn-rift stages reflect how sedimentation gradually outpace accommodation space creation. The overlying thick post-rift succession shows no evidence of rifting besides a minor fault-displacement along the Øygarden Fault Zone in the Late Triassic, reflected by slight wedging. Meanwhile distinct interchanging sand- and mud-dominated intervals reflect strong climatic fluctuations during the post-rift. The spatio-temporal heterogeneity in fluvial facies makes stratigraphic correlation challenging and is further complicated by discontinuous surfaces caused by basin floor tilting. With this study, classical sequence stratigraphic models are evaluated and revised against the observations from the Horda Platform. The stratigraphic model presented takes into account the dynamics of strain along faults through time and space and the resulting diachronic boundaries between the rift stages.
\end{abstract}

Key-words: Continental rift-basin dynamics, Permian-Triassic, Horda Platform, tectonostratigraphy, fault growth, climate

\section{1 | INTRODUCTION}

Delineating alluvial sequences in rift basins is challenging as stratigraphic concepts were originally developed for marine successions in passive-margins (Van Wagoner et al., 1988; Shanley and McCabe, 1994; Catuneanu, 2006; Jarsve et al., 2014) where accommodation is primarily controlled by cycles of sea-level changes (Posamentier and Vail, 1988; Catuneanu, 2006 Catuneanu et al., 2009). In contrast, rift basins are systems where major fault zones and rotated 
fault blocks form through extension (Anders and Schlische, 1994). Accommodation is primarily controlled by tectonic activity with areas of high accommodation forming concurrent to close-by areas of uplift and erosion (Holz et al., 2017). Resulting asynchronous surfaces (Rodríguez-López et al., 2014) complicate stratigraphic correlation (Frostick et al., 1992) and lowers the capability for predicting the location and prevalence of potential reservoir units in the subsurface.

This study investigates the influence of fault-growth on accommodation and sedimentation in the Permian-Triassic alluvial succession in the Horda Platform, Norway. It compares the characteristics to established models of continental rift basin fill (Prosser, 1993: Nøttvedt et al., 1995; Gawthorpe and Leeder, 2000; Morley, 2002; Holz et al., 2017), where important discrepancies remain. Through a seismic stratigraphic analysis and well-log correlation, the Permian-Triassic succession is sub-divided into six sequences, which each represent a stage in the rift development. Thickness variations, geometric- and lithological trends reflect facies- and accommodation space changes controlled by interchanging tectonic and climatic variations.

The Permian-Triassic succession in the Horda Platform is one of the thickest and most widespread in the northern North Sea Basin (Figure 1a) (Goldsmith et al., 2003), but also one of the least understood. Commercial interest in the succession is increasing as the upper sand-rich interval in the Smeaheia Fault Block (Figure 1) represents a potential target for geo-sequestration within the NCCS project (Furre et al., 2018). Although the North Sea is a well-known intraplate rift (Evans et al., 2003), exploration wells have primarily targeted footwall crests (Pegrum and Spencer, 1990; Spencer and Larsen, 1990), leaving deposits in deeper hanging-wall sub-basins unexplored. Despite extensive petroleum exploration in the Horda Platform, the entire Permian-Triassic interval thus remains largely untested. The Horda Platform was characterized by continental sedimentation in arid- to semi-arid conditions during the Permian-Triassic (Nystuen et al., 1989; Steel and Ryseth, 1990; Nystuen and Fält, 1995; Goldsmith et al., 2003; Korte et al., 2005; Nystuen et al., 2014; McKie 2014). The deposits are largely barren of palynomorph assemblages, making a regional correlation difficult (Lervik, 2006; Jarsve et al., 2014), and is further hampered by few penetrating wells, lacking core-material and a common low seismic resolution. Existing studies of northern North Sea Permian-Triassic deposits mainly focus on the Tampen Spur where data coverage is denser (e.g. Nystuen et al., 1989; Steel and Ryseth, 1990; Nystuen and Fält, 1995; Müller, 2003; Nystuen et al., 2014).

\section{2 | GEOLOGICAL SETTING}

The northern North Sea rift comprises series of dominantly N-S trending grabens and halfgrabens between the Norwegian mainland to the east and the Shetland Platform to the west (Færseth, 1996; Phillips et al., 2019) (Figure 1b). A Precambrian to Lower Palaeozoic crystalline 
crust is covered by a sedimentary succession ranging in age from Devonian to Cenozoic (Zanella et al., 2003).

\section{1 | Tectonics and climate}

Late Ordovician to Late Silurian-early Devonian collision between the palaeocontinents Laurentia and Baltica formed the Caledonian Mountain Chain (Coward, 1995; Roberts, 2003). Gravitational collapse of Caledonian crust resulted in extension and development of Devonian basins (Andersen et al., 1991; Fossen, 1992; Osmundsen and Andersen, 2001; Braathen et al., 2002).

Carboniferous to Early Permian extension (Heeremans and Faleide, 1991) was followed by a significant rifting event in the Late Permian to Early Triassic period where E-W/SE-NW extension resulted in the creation of graben- and half-graben systems (Færseth, 1996; Odinsen et al, 2000a; Coward et al., 2003; Bell et al., 2014; Whip pet al., 2014; Duffy et al., 2015; Fazlikhani et al., 2017; Phillips et al., 2019). Early Triassic rifting waned throughout the Mid-Triassic to Late Jurassic leading to a broader and larger continuous marine basin. Linkage of the Arctic and Tethys oceans in the early Rhaetian led to transgression within the continental Triassic basins (Ziegler, 1992). Meanwhile, climate changed gradually through Middle Triassic to Early Jurassic from arid to humid, contemporaneous to the northward drift of southwestern Baltica, including Scandinavia (Røe and Steel, 1985; Steel, 1993; Nystuen et al., 2014) A second Late Jurassic to Early Cretaceous rift phase formed the "North Sea triple-junction", after which subsidence and mild tectonic inversion dominated from the Late Cretaceous and onwards (Færseth, 1996; Odinsen et al., 2000a; Gabrielsen et al., 2001; Coward et al., 2003).

\section{2 | Key structures}

The Triassic basin is restricted largely to a $170-180 \mathrm{~km}$ wide $\mathrm{N}-\mathrm{S}$ trending depression, flanked to the east by the Øygarden Fault Zone and to the west by the Hutton alignment (Odinsen et al., 2000 a, b). The Triassic rift axis was located below the Horda Platform (Roberts et al., 1995) before migrating westward, resulting in the development of the Viking Graben during the second rift phase (Færseth et al., 1995; Færseth, 1996; Ter Voorde et al., 2000).

The Horda Platform forms a 300x100 km N-S elongated structural high bounded to the west by the northern Viking Graben and to the east by the Øygarden Fault Zone (Whipp et al., 2014). Several 1-2.5 km thick packages of Triassic strata lie within the large eastward-dipping halfgrabens (Smeaheia, Tusse and Svartalv fault blocks) bounded by westward dipping, thick-skinned faults (Øygarden, Vette, Tusse, and Svartalv fault zones). The faults are spaced 15-20 km apart and exhibit throw in the range of 4-5 km (Mulrooney et al., 2020) (Figure 1c). 


\section{3 | Stratigraphic framework}

On the Norwegian Continental Shelf, basement is defined as pre-Devonian bedrock (Coward, 1995; Fazlikhani et al., 2017). The pre-Permian-Triassic rocks in the Horda Platform are generally considered crystalline basement (Norsk Hydro Produksjon, 1984; Phillips Petroleum Company, 1996; Riber et al., 2015). Well 32/4-1 T2 allegedly penetrates Devonian strata, rather than crystalline rocks, but this is uconfirmed by dating techniques. The carbonate and evaporite-rich Zechstein Group, which underlies the Triassic in the central and southern northern North Sea (Lervik, 2006), is absent in the Horda Platform.

The stratigraphic framework for the Triassic succession in the northern North Sea has long been a subject of debate, largely due to poor biostratigraphic control (e.g. Vollset and Doré, 1984; Nystuen et al., 1989; Steel and Ryseth, 1990; Underhill and Partington, 1993; Nystuen and Fält, 1995; Odinsen et al., 2000a; Goldsmith et al., 2003; Lervik, 2006; Nystuen et al., 2014). A review by Lervik (2006) collated available information to systemize and unify the stratigraphic nomenclature schemes, which are applied here. Jarsve et al., (2014) used seismic facies and regionally continuous seismic reflections to subdivide and map the central North Sea Triassic deposits. The same procedure is applied here to the Triassic Hegre Group in the Horda Platform.

The Hegre Group was deposited in a continental basin covering most of the current North Sea area (Steel and Ryseth, 1990; Frostick et al., 1992; Steel, 1993; Nystuen and Fält, 1995; McKie et al., 2010; McKie, 2014; Jarsve et al., 2014; Nystuen et al., 2014). The succession features several coarsening- and fining-upwards alluvial sandstone and mudstone sequences of higher- and lowerorder (Nystuen et al., 1989; Steel and Ryseth, 1990). Based on these trends, the Hegre Group is officially divided into three formations: Teist, Lomvi, and Lunde (Vollset and Doré, 1984) (Figure 2). Lervik (2006) revised the stratigraphic nomenclature by Vollset and Doré (1984), and established the scheme applied and summarized here and in Figure 2:

The Teist Formation (Lower Triassic): interbedded red-coloured mudstones, marls, and meterthick calcareous sandstone beds (Lervik, 2006), deposited in ephemeral streams and distal mudbasins (Nystuen et al., 2014).

The Lomvi Formation (Lower to Middle Triassic): blocky, kaolinitic sandstones, extending laterally for hundreds of metres with thin, interbedded marls and mudstones (Lervik, 2006). A fluvial origin (Vollset and Doré, 1984) as well as aeolian reworking is evidenced by the presence of very well-rounded sand grains and a high maturity (Nystuen et al., 1989). 
The Alke Formation (Middle to Upper Triassic): red/brown/grey/green mudstones and subordinate sheet sandstones (Lervik, 2006), laid down in lacustrine and terminal basins with proximal alluvial fans (Nystuen et al., 2014).

The Lunde Formation (Upper Triassic): overall fining-upwards unit of interchanging fluvial sandstones, red mudstones, and marls deposited in fluvial and lacustrine systems (Lervik, 2006; Nystuen et al., 2014).

Overlaying the Hegre Group is the Rhaetian to Sinemurian Statfjord Group (Lervik, 2006). This is a sandstone-rich coarsening-upwards succession, dominated in the lower part by sinuous to straight stream deposits (Nystuen et al., 2014). The succession is thin $(<50 \mathrm{~m})$ in the eastern Horda Platform and thickens west towards the Viking Graben (Figure 3). The overlying Jurassic deltaic and marine Dunlin and Brent groups are more or less uniformly thick across the Horda Platform but thicken dramatically in the Viking Graben (Husmo et al., 2003; Fraser et al., 2003). The Cretaceous succession thickens towards the Øygarden Fault Zone in the Horda Platform, being truncated by overlying Quaternary strata, while west of the Horda Platform, the succession thickens significantly towards the Viking Graben where it is buried by Cenozoic deposits in a large synclise (Faleide et al., 2002; Copestake et al., 2003; Surlyk et al., 2003).

\section{3 | DATA AND METHODS}

\section{1 | Seismic analysis}

Seismic sequences, representing certain depositional and/or structural stages in basin development, were mapped using Petrel E\&P Software Platform. The sequences were defined based on internal reflection signatures (seismic facies; Figure 4) related to geometry, continuity, and frequency, reflecting changes in depositional style and/or lithology (Roksandic, 1978; Strecker et al., 1999). Surfaces defining the base of the sequences were generated from mapped horizons and used to constrain sequence thicknesses. Delineating boundaries of the seismic sequences are commonly manifested as high-amplitude, continuous seismic reflections, coinciding with lithological variations in well-logs. These result from erosion, non-deposition, or regional changes in the physical sedimentary environment, and represent possible time-lines between intervals of specific depositional patterns and/or of differential geometry (Strecker et al., 1999).

The GN1101 (Gassnova AS) and a subset of the NVG (CGG Services AS) Horda post-stack time migrated 3D seismic surveys, supplemented with regional 2D seismic surveys (NSR) provide the primary datasets applied in this study (Figure 1c). 


\subsection{Well data}

Gamma-ray (GR) logs from wells 32/4-1 T2, 31/6-1 and 31/2-4 $R$ has been applied to inform seismic to well correlations and recognise stratigraphic boundaries (Figure 5). Coupled with sedimentological descriptions (e.g., lithology, grain size and sorting) from well reports, GR-logs were used to infer depositional environments (Figure 4). Since wells only penetrate footwall crests, facies changes in deeper basin parts were inferred from seismic. Depositional environments proposed herein are based on comparative analysis to observations in lithologically equivalent rock formations in the Tampen Spur area (i.e., Nystuen and Fält, 1995; Nystuen et al., 2014). Stratigraphic divisions were assigned with respect to the scheme presented by Lervik (2006) for the northern North Sea province. The diachroneity, however, means that although descriptively useful, this lithostratigraphic sub-division is of little value for correlation purposes. Therefore, rather than trying to correlate sandstones (which are laterally discontinuous in fluvial systems) we connect overall fining- and coarsening-upwards intervals, and if possible unconformities representing flooding or sub-aerial erosional surfaces.

Even though forty wells penetrate Triassic strata on and adjacent to the Horda Platform, very few have been drilled more than a few metres into Triassic rocks, and only wells 32/4-1 T2 and 31/61 are drilled into Pre-Triassic strata. Well 31/2-4 R logs $2700 \mathrm{~m}$ of Triassic strata without encountering pre-Triassic rocks and offers the only available Triassic core-material in the Horda Platform from the lowermost 8 meter of the well. Two additional wells (31/4-3 and 31/5-3 S) (Figure 1) in the outer skirts of the study area $\log 2633 \mathrm{~m}$ and $939 \mathrm{~m}$ of Triassic strata, without reaching basement.

\section{4 | SEISMIC STRATIGRAPHIC ANALYSIS}

\section{1 | Upper and lower boundaries}

The Permian-Triassic succession is bounded by and contain internal surfaces, that are mappable across the whole study area. The surfaces are presumed to represent depositional shifts during basin fill. The base Permian-Triassic surface (Base PT) is a major sub-aerial unconformity between clastic deposits and crystalline rocks (i.e., pre-Devonian metamorphic and/or Devonian metasedimentary rocks). Base PT is a strong seismic reflection, displaying a topographic relief in footwalls to the major fault zones (Figure 6). The relief is most pronounced in the footwall to the Vette Fault Zone where it displays drainage catchments and incisions (Figure 6b). Base PT is readily mappable in major parts of the study area, except to the northwest where it becomes less 
pronounced, probably due to large depth combined with overburden stratigraphy, structures, and fluids influencing the imaging quality. Beneath the surface are a series of high-amplitude, shallowdipping, sigmoidal reflections, possibly representing Devonian shear zones (Fazlikhani et al., 2017; Mulrooney et al., 2020).

The upper sequence boundary (Base Statfjord Gp) marks a turnaround from fining-upwards into coarsening-upwards in well-logs (Nystuen et al., 2014) (Figure 5), but is generally poorly resolved in seismic, and thus constrained by careful seismic-well-tie. The surface is occasionally truncated to the northeast in the Smeaheia Fault Block. This may be related to a significant unconformity recognised in the greater North Sea area, resulting from Middle Jurassic to Early Cretaceous erosion, whereas in the northern North Sea the Triassic is conformably overlain by Lower Jurassic marine mudstone and shale (Goldsmith et al., 2003).

\section{2 | Permian-Triassic seismic sequences}

Six seismic sequences (S1-S6) are defined within the Horda Platform area (Figure 3; 5). The sequences are delineated by surfaces resulting from non-deposition, flooding, erosion, or particularly strong lithological contrasts (Strecker et al., 1999). Variations in seismic expressions represent transitions in depositional regime brought about by tectonic and climatic changes, shifts in provenance, or a combination. Overall, the succession thickens northwest and internally towards the hanging-walls of the major fault zones. Well-bores record an average thickness of $1664 \mathrm{~m}$ of this succession in the northern North Sea (Goldsmith et al., 2003), but since wells are generally located in footwall crests, they essentially record minimum thicknesses. Seismic data implies thicknesses in excess of $3000 \mathrm{~m}$ in the deepest hanging-walls (estimated from well depths). As the study area is outside the Zechstein Salt limit (Figure 1a), the thickness variations are not halokinetic-induced, but instead owing to half-graben accommodation distribution (Goldsmith et al., 2003).

\subsection{1 / Sequence 1}

\section{Description}

The base of Sequence 1 (S1) is bounded by the high-frequency Base PT. The sequence is predominantly located in the deep hanging-walls with main depocentres west in the Svartalv and Tusse fault blocks (Figure 3; 7). Except for a few scattered patches, the sequence is absent east in the Smeaheia Fault Block and in the footwall to the Tusse Fault Zone. The patches are mapped as wedges that thickens toward the major faults, but are less prominently wedge-shaped compared to sequences 2 and 3 (described below). Internal reflections are mostly low-frequent, sub-parallel 
and bifurcating (Facies 5; Figure 4), onlapping onto footwalls and the reliefs in the Base PT surface (Figure 8). A serrated GR-signature with low values characterise the well-log through S1 (Figure $5)$.

\section{Interpretation}

Sequence 1 strata developed in a set of isolated basins during the earliest rift development and represents the onset of rifting and initial sedimentation following the exhumation and erosion of pre-Permian-Triassic strata (Figure 9a) and is labelled an early syn-rift here. The Base PT surface represents a sub-aerial unconformity, and its rugged surface is interpreted as intra-basinal ranges. These affected sediment routing and acted as local sources additional to the uplifted rift shoulders on active fault segments. Sediment was deposited in hanging-wall blocks, with main depocentres west and central-south. The patchy distribution of strata appears to be linked to topographic lows in the Base PT surface. The serrated log-trend with low values suggests dominantly sandstones deposited as thin sand-beds, likely of sheet-flood origin, which is characteristic to arid stream systems where discharge rapidly changes (Nystuen et al., 2014; McKie, 2014).

\subsection{2 | Sequence 2}

Description

Sequence 2 (S2) is bound at its base by the thick, high-frequent Base S2, except in the Tusse and Vette Fault Zone footwalls where it rests directly on the Base PT (Figure 5). Wedges that thicken toward the major fault zones are characteristic to the stratigraphy. The greatest thickness is northwest in the Lomre Terrace followed by the Svartalv and Tusse fault blocks (Figure 7). S2 partially blankets the Smeaheia Fault Block and the Base PT where S1 did not develop (Figure 7e.3).

Internal reflections onlap onto the hanging-wall dip-slope, while showing drag and aggradation close to the footwall scarp (Figure 8). Distal and central parts of the fault blocks remain dominated by sub-parallel reflections (Facies 5). In hanging-walls to the active faults, reflections become more bifurcated and lensoid (Facies 3; Figure 4). The reflections progressively steepen towards footwall scarps and decrease in wavelength and -strength, taking on a chaotic, diffracted appearance (Facies 1; Figure 4). Well-logs are highly serrated with high GR-values (Figure 5). 


\section{Interpretation}

S2 represents the second syn-rift stage as inferred from the geometry, seismic facies, and onlap relations. Stronger wedging reflects increased slip-rates during this time (Figure 3). Strain had shifted northwest to the Troll Fault Zone with lesser movement along the Tusse Fault Zone and segments of the Vette Fault Zone. The thin deposits in the Smeaheia Fault Block indicate initial movement along the Øygarden Fault Zone. Intra-basinal topography was negligible and accommodation was to a larger extend controlled by faulting.

The serrated high-value GR-signals suggests deposition dominated by lacustrine mudstones and sheetflood sandstones (Figure 9b). The coarser grain fraction in the Smeaheia Fault Block reflects both the more proximal position and minor subsidence degree, in accordance with the rift model of Prosser (1993). The coarse sediments were deposited in fault-scarp derived alluvial fans, as indicated by the tilted, chaotic reflections here.

\subsection{3 / Sequence 3}

\section{Description}

Wedge-shapes persist in Sequence 3 (S3) with thickening toward hanging-walls, now also towards the Øygarden fault Zone (Figure 7e.1). The high-frequent Base S3 marks a transition to generally low GR-values and blocky log-motifs, upwards transitioning to more serrated motifs with fining- and coarsening-upwards high-value GR-responses (Figure 5). Hanging-walls are characterised by down-dipping, contorted, chaotic reflections (Facies 1). Occasionally in footwalls occurs a prograding set of sub-parallel, bifurcating reflections (Facies 3) that flatten out or downlap onto horizontal reflections (Facies 5) in basin centres. This downlap surface coincides with an increase in coarse clastics.

\section{Interpretation}

S3 represents the third syn-rift stage where fault segments are partially or fully linked to form three (mostly) disconnected half-graben basins as opposed to the isolated basins in S1 and S2 (Figure 9c). Asymmetry is recorded in equivalent units in the Stord Basin and Tampen Spur, suggesting a regional extensional event (Müller, 2003; Nystuen et al., 2014). The facies variation owes to the asymmetric subsidence creating differential sedimentary conditions across basins (cf. Prosser, 1993). Dipping, aggrading hanging-wall reflections indicate tilted depositional bodies, such as alluvial fans (Moscariello, 2018). Their contorted, diffracted appearance is characteristic to mass flow deposits (Dolson et al., 1999) where high grain-size variability and dis-orderly bedding obscure reflections (Miall, 2010). Towards the fan-apron, mass-flow processes transition 
into the flow regime, reflected by the channelization in this zone (Moscariello, 2018) (Figure 8). Sheet flood deposits, generated from margin talus cones, are dispersed into mudstone-rich floodplains as reflected by abrupt shifts in reflection strength and sandstone-mudstoneinterbedding in well logs (Nystuen et al., 1989). Lensoid reflections commonly indicate channelization (Schwab et al., 2007), likely in low-sinuous braided-streams, as interpreted in equivalent Tampen Spur sandstones (Nystuen and Fält, 1995; Nystuen et al., 2014). Finingupwards well-log responses and lateral accreting reflections likely reflect bar migration (Bridge and Tye, 2000; Abreu et al., 2003; Schwab et al., 2007; Miall, 2010). In hanging-walls of active fault-bounded basins, channels tend to cluster in axial positions (e.g. Gawthorpe and Leeder, 2000), while footwall drainage forms part of the alluvial fan system, draining antecedent (Frostick et al., 1992; Rhee, 2006), both features complying to observations.

\subsection{4 / Sequence 4}

Description

The base of Sequence 4 (Base S4) is a medium-strong amplitude reflection with frequent swales (Figure 8) that marks a change in seismic facies from S3 to S4. The stratigraphic geometry is markedly less wedge-shaped than the older basin fill, appearing as tabular units across the Horda Platform with slight thickening towards the Øygarden Fault Zone. Internal reflections are dominantly sub-parallel with frequent swales and lenses that occasionally concentrate and stack to form larger bowl-shaped, incising features (Facies 2). Close to the Øygarden Fault Zone, reflections are persistently chaotic, contorted and dipping (Facies 1).

In well-logs, the transition from S3 to S4 is marked by a sharp shift to blocky, low-value GR-signals. Upwards, GR-values increase along with the degree of serratedness (Figure 5). Well-log reports indicate an increase in carbonaceous horizons upwards in the eastern sections simultaneous to a decrease in western sections.

\section{Interpretation}

Extensive sand deposition took place across the basin in S4 (Figure 9d). The coarse-grained lithology, lack of facies- and thickness variations across the basins, and tabular geometry, are all features indicative of faulting ending (Prosser, 1993; Holz et al., 2017). The erosive nature and regional extent of Base S4 suggests this represents a subaerial unconformity. The shift into tabular geometry coincides with the sharp introduction of clean sandstones; a change also recorded in the Tampen Spur (Steel and Ryseth, 1990; Nystuen and Fält, 1995; Nystuen et al., 2014), UK (Vollset and Doré, 1984; Nystuen et al., 1989; Frostick et al., 1992; Goldsmith et al., 2003) and northern 
Norwegian-Danish Basin (Lervik, 2006), suggesting a regional similarity in depositional characteristics during this time. The GR-signals suggest dominance by amalgamated, homogenous sandstones, becoming less amalgamated upwards (Figure 5). The amalgamated sandstones indicate high sedimentation rates and low preservation potential for fin-grained deposits (Shanley and McCabe, 1994). These tightly stacked sandstones can be seen in multi-storey channel units (Mitten et al., 2020), where frequent avulsion is commonly generated by braided streams (Walker, 1976; Bourquin et al., 2009), or in aeolian dune deposition, where high sedimentation rates may enhance amalgamation (Kjemperud, 2008; Schomacker, 2008). Meanwhile, alluvial fans characterised the marginal deposition, as suggested by the contorted, dipping reflections here (Figure 8). Carbonaceous horizons in alluvial successions, reflected by the low peaks, may be of pedogenic origin (Kraus, 1999), a process which requires continuous landscape stability, or aggradation where sedimentation is low, or even non-deposition (Müller et al. 2004).

\subsection{5 / Sequence 5}

\section{Description}

The strong Base S5 reflection coincides with a pronounced shift in well-log trend to Sequence 5 (S5). S5 is of uniform thickness across the basin, except local wedges towards central fault segments, most pronounced towards the Øygarden Fault Zone (Figure 3). Parallel, laterally consistent reflections (Facies 5) dominate internally with occasional lenses and bifurcation (Facies 3) (Figure 8). Chaotic reflections (Facies 1) continue to dominate along the margin. Highvalue, serrated GR-signals are characteristic with bell- and funnel-shapes, all arranged in an overall decreasing-upwards (Figure 5). Values are lower in the Smeaheia Fault Block, as general for all sequences in this fault block. Similar trends are mapped in the Stord Basin by Nipen (MSC 2020) and in Tampen Spur (Müller, 2003).

\section{Interpretation}

Parallel, horizontal reflections suggests steady depositional rates on a flat uniformly subsiding surface, such as a basin plain, without significant erosive features, such as channels (Dolson et al., 1999). The low thickness and overall tabular geometry indicates a period of comparative tectonic quiescence with local extension along the Øygarden Fault Zone (Figure 9e). Drainage would have been toward topographic depressions, created in the hanging-wall to zones of strain accumulation, which likely hosted rift lakes, but elsewise moved un-prohibited across the postrift landscape (Gawthorpe and Leeder. 2000). The serrated GR-motif reflects a heterogeneous lithology where high-values represent floodplain and lacustrine deposition (Strecker et al., 1999), 
while low-values represent sandstones deposited in small channels (bell-shapes) and as sheetfloods or crevasse splays (funnel-shapes) (Nystuen et al., 2014) (Figure 4). The increasing GRvalue suggests more fine-grained deposition, which can reflect either (1) a decrease in sedimentation rates, which may be induced by waning faulting, or (2) a climatic change leading to higher water tables and more extensive lacustrine deposition. The eastward lateral coarsening across the three fault blocks is due to increasing proximity, as alluvial fans dominated the margins, suggested by the dipping and chaotic reflections towards the Øygarden Fault Zone. The low-value peaks in the Smeaheia Fault Block, interpreted as carbonaceous horizons, may be due to pedogenesis.

\subsection{6 / Sequence 6}

\section{Description}

At base of Sequence 6 (S6), the strong Base S6 reflection coincides with a sharp decrease in GRvalues, most pronounced central and east (Figure 5). S6 thickens significantly westward, while being truncated by the boundary to the overlying Statfjord Group locally in the Smeaheia and Vette fault blocks (Figure 7; 8). Thin S6 deposits may be present in the Øygarden Fault Zone footwall unit (Figure 3). Internal reflections diverge westward, characteristically strong, continuous and parallel (Facies 4, 5), with occasional bifurcations, lenses and swales (Facies 2).

The well-logs display an overall fining-upwards trend, arranged in interchanging intervals dominated by either serrated GR-motifs with bell-shapes or by blocky low-valued GR-signals (Figure 5). Based on these alternations, S6 can be subdivided into four sub-sequences (S6.1-4). S6.1 thickens eastwards, S6.2 is uniformly thick, while S6.3 and S6.4 thicken towards west. Proximally, the low-valued intervals are thicker, more consistent, with a blocky responses, while getting more serrated with distality. Pronounced low-peaks in the serrated intervals, most concentrated in S6.1 in the eastern $\log$ (32/4-1 T2), stand out from the GR-motif (Figure 5).

\section{Interpretation}

The sudden decrease in GR-signal value across the boundary from S5 to S6 reflect an influx of coarse sediment with an introduction of large quantities of sand, likely due to source denudation during waning rifting (Blair, 1987). The overall fining-upwards reflect gradually filling of the basin, simultaneous to a decrease in sedimentation rate. The differential GR-signals reflect alternating sandstone and mudstone-dominated intervals that overall fine upwards and westward (Figure 5). The high-value intervals represent mudstone-rich periods, while the blocky, low-value intervals represent amalgamated sandstones. The amalgamation rate decreases with 
distality, reflecting how the sandstones split up into several thinner sandstone collections in between mudstone-rich units. The sandstone bodies in the lower part (S6.1 and S6.2) are of braidstream origin, based on their stacked appearance and blocky GR-profile, while higher sinuosity channel-belts prevailed upwards and westward, indicated by the increasing bell-shapes and preservation of mudstones, characteristic to single-storey channels (Miall, 2010) (Figure 9f). Increased sinuosity through the Upper Triassic was also recorded in the Tampen Spur by Nystuen et al., (2014). The high-frequent low-peaks represent carbonate horizons, which are indicative for low sedimentation rates and pedogenic calcrete production, possibly on interfluves (Müller et al. 2004).

During S6 deposition, the main depocentre shifted west, reflected by the thickness variations (Figure 7) and divergent reflections (Figure 8), representing westward progradation. The slight wedging in S6.1 reflects the inherited topography from the syn-rift stage, a phenomenon typical to early post-rifts (Prosser, 1993). The truncated reflections in the top indicate erosion, possibly representing a sub-aerial exposure prior to deposition of the Statfjord Group.

\section{5 | DISCUSSION}

The breakdown of the strata that developed in concert with Triassic rifting in the Horda Platform area provides a step-by-step record of the rift phases in the region. Comparative evaluation of the rifting in the Horda Platform area against other models of rift basin evolution (Prosser, 1993; Nøttvedt et al., 1995; Gawthorpe and Leeder, 2000; Morley, 2002; Holz et al., 2017) is possible with the data quality offered here. Generally, the balance between generation of tectonically driven accommodation versus sedimentation rate is reflected in stratigraphic patterns within rift basins, which are commonly considered under-filled in continental settings. Thus, sedimentationrate is the rate-limiting step, outpaced by increasing accommodation, especially in proximity to basin-bounding faults. Sediment delivery is further affected by sediment routing, in turn controlled by catchment areas along with tectonic obstacles (de Almeida et al., 2009; Henstra et al 2016).

\section{1 | Pre-rift configuration and implications on Permian-Triassic sedimentation}

The range-like reliefs in the Base PT (Figure 6) affected the distribution and routing of sediment through S1 into S2. The origin of the relief is difficult to unravel but it either (1) existed prior to Permian-Triassic rifting or (2) was created as a result of footwall uplift and denudation.

(1) If the landscape pre-dates the rifting, the relief formed as a continuation of the mainland Caledonian topography prior to activation of the Øygarden Fault Zone. The smooth and subdued 
relief in the hanging-wall was caused by erosion and deposition from stream avulsion during block tilting. The transitions in seismic facies below the Base PT are reminiscent of compositional heterogeneity and varying structural fabric in e.g. dikes and nappe-structures (Fossen et al., 2017; Lenhart et al., 2019), which are characteristic of the crystalline rocks in the onshore Caledonian massif (Boundy et al., 1992).

(2) If the landscape is contemporaneous to rifting, the relief was formed by footwall uplift, and associated development of catchment areas (Elliot et al., 2012), similar to those observed in the Tusse Fault Block (Figure 5). Commonly, antecedent streams drain away from the crests at a higher slope with limited avulsion (Frostick et al,, 1992), incising reliefs as observed here. Incisions resulting from footwall uplift are expected to show drainage patterns towards the hanging-wall, away from the fault (Trudgill, 2002), which is not the case in the Smeaheia Fault Block where incisions appears to create drainage paths towards the fault (Figure 6b). This indicates that the Smeaheia Fault Block was not tilted until later in the syn-rift so that it formed a palaeo-slope dipping west during the initial movement of the Vette Fault Zone (Figure 9a.2).

The presence of Devonian strata within the denudated area would constrain whether the relief is related to onshore topography. In the Smeaheia Fault Block, Devonian red granitic conglomerates underlies the Base PT according to the 32/4-1 T2 well-report (Phillips Petroleum Company Norway, 1996). A thick succession of distinct seismic facies is indicated below the Base PT (Figure 3) (Christiansson et al., 2000), which corresponds in thickness to Devonian basins in the Moray Firth and Shetland Platform (Marshall and Hewett, 2003). The strata, now sectioned by faults, exhibits wedging towards the eastern margin, indicating a syn-rift phase. This corresponds with Devonian post-orogenic extension (Færseth, 1996; Fossen et al., 2017) documented in the surrounding regions (Neumann et al., 2004). Except for this well, pre Permian-Triassic rocks north of the Moray Firth and Horda Platform are, however, Caledonian crystalline bedrock (Marshall and Hewett, 2003) and without dating, the presence of Devonian strata in the area cannot be proven.

With the available constraints, the Base PT relief is linked to erosion during footwall uplift. The wide relief-zone in the Smeaheia Fault Block (Figure 6b) likely combine the two theories, where the first was enforced by the second as the Øygarden Fault Zone was offset; As indicated by thickness maps and the incision patterns in the Base PT, the Vette Fault Zone moved prior to the Øygarden Fault Zone, which accelerated at the late stage of rifting (S3) (Figure 7). At onset of movements of the Øygarden Fault Zone, the Smeaheia Fault Block was tilted and the relief was buried. 


\section{2 | Controlling factors on deposition}

The varying thickness in sequences 1-6 (Figure 7) reflects that accommodation was a strong controlling factor on deposition during most of the Permian-Triassic. The syn-rift succession (Figure 7e) experienced three rift stages, reflected by strain migration as faults propagated and linked (Figure 7e.1-3). The interchanging mud/sandstone-dominance with decreasing faultcontrol in sequences 4-6 indicate that with waning rifting, accommodation diminished as a depositional control, and the effect was enhanced or even overprinted by climatic variations.

\subsection{1 / Sequence 1: tectonics and pre-rift topography}

During S1 deposition, the area was immature with several small, heterogeneous basins developed (Figure 7e.3). Accommodation was irregularly distributed; in the western Horda Platform, depocentres are well-developed in hanging-walls and stretching onto footwalls, while the central fault block only saw shallow, isolated hanging-wall depocentres, and the eastern fault block experienced non-deposition. The wider areas of high sediment accumulation to the west coincide with long, connected fault-zones, in contrast to the segmented faults to the east.

The sandy, homogeneous lithology (recorded in the western fault block basin) reflects a steady supply of coarse sediment at a rate higher than the rate of accommodation so that floodplain fines were unpreserved in between the sheet-like ephemeral stream- and flash flood-sands. Large quantities of immature debris would have been locally available in the high-relief landscape (Lambiase and Bosworth, 1995), further supporting a high sediment supply rate. A high supply of sediment is expected as S1 was deposited on a sub-aerially exposed, topographic surface, meaning that large quantities of immature debris would have been locally available (Lambiase and Bosworth, 1995). In addition, a response to the climate being arid, mechanical weathering would prevail in the source area, favouring the production of sand over clay (Nystuen et al., 2014).

\subsection{2 / Sequence 2: tectonics}

In the second stage, the epicentre of faulting shifted northward and accommodation zones widened concurrently with faults propagating and strain expanding east (Figure 7e.2). Subsidence outpaced sedimentation (Figure 10) as rifting increased, demonstrated by the fine-grained (lacustrine) lithology and highly serrated GR-response in well-logs. Contemporarily, the proximal area experienced continued non-deposition, suggesting persistently low subsidence and incipient faulting in this zone. Furthermore, remnants of pre-rift topography were probably not buried before termination of S2 deposition. Pronounced reliefs, related to antecedent drainage (Trudgill, 2002; Wise and Noble, 2003; Cowie et al., 2006; Elliot et al., 2012), remained in footwall crests. 
Thus, the rift was structurally more developed compared to the stage of S1, but unevenly distributed accommodation persisted.

\subsection{3 / Sequence 3: tectonics}

By the end of the third stage, strain had migrated east, and linked faults formed major fault zones dividing the Horda Platform into half-graben basins (Figure 7e.1). Fault-junctions locate breached relay zones, commonly between overstepping fault segments (Peacock and Sanderson, 1994). In response, the strain was distributed along the faults, and deposition widened onto the footwalls. The basin was in a mature stage with deposition from hanging-walls to footwalls in all fault blocks (Figure 10). During the course of S3, the basin transitioned from rift climax (S3.1) into a waning rift (S3.2), reflected by the fining- into coarsening-upwards trend, separated by a flooding surface. The fining-upwards (S3.1) reflects retrogradation relating to accommodation outpacing sedimentation as subsidence reached its maximum (Holz et al., 2017). The subsequent coarsening-upwards (S3.2) evince a progradational trend, as sedimentation outpaced subsidence.

Stratigraphic boundaries in synrift successions are often discontinuous, as a flooding surface in the hanging-wall may form synchronously to subaerial exposure in the footwall due to concurrent uplift here (Gawthorpe et al., 1994; Withjack et al., 2002; Holz et al., 2017). The recorded lithological trend is related to the development on footwall crests where the influence of lacustrine facies is minimal (Holz et al., 2017). The trends and boundaries may therefore represent other inducing mechanisms than those recorded in hanging-walls by e.g. Prosser (1993) and Martins-Neto and Catuneanu (2010). A flooding surface in the footwall can form under different, possibly interplaying, scenarios: (1) subsidence balancing as faulting wanes; (2) low sedimentation rates; (3) decreasing precipitation in hinterlands and thus less erosion in the source area (Nystuen et al., 2014); (4) increased precipitation in the basin leading to lake level rise and transgression onto the footwall (Holz et al., 2017). The flooding surface in the middle of the wedge-shaped sequence, present on the footwall crest even, reflects a pause in faulting, which hampered basin floor tilting and balanced subsidence.

\subsection{4 / Sequence 4: climate}

Sequence 4 represents a period with a low A/S (Figure 10), reflected by the amalgamated sandstone-rich succession. Erosion of basin shoulders may have expanded the catchment area, which increased the sediment supply (Nystuen et al., 1989; Nystuen and Fält, 1995). The removal of syn-rift relief allows for transverse drainage-systems, which enhance the dispersal of coarse sediment across the basin (Prosser, 1993). 
The origin of the sandstones is a subject of debate; Steel and Ryseth (1990) documented a pebbly nature and small fining-upwards motifs in equivalent Tampen Spur sandstones, indicating a fluvial origin (Vollset and Doré, 1984). Nystuen et al. (2014) suggested aeolian influence, based on high sorting-degree and -maturity. Aeolian deposits are abundant in the Triassic across Europe (McKie and Williams, 2009) and arid rift basins are important sites for aeolian deposition (Prosser, 1993), as the linear topography creates tunnel-winds that abuts the steep rift slopes, leading to grain fall-out (Howell and Mountney, 1997).

Aeolian sandstone preservation requires sufficient accommodation relative to accumulated sediment (Kocurek and Havholm, 1993), which may be achieved by thermal subsidence, sediment loading, or -compaction (Blakey, 1988; Kocurek and Havholm, 1993; Mountney et al., 1999; Rodríguez-López et al., 2014), the latter two enhanced by increasing sedimentation (Nøttvedt et al., 1995; Kjemperud, 2008; Schomacker, 2008). Aeolian deposition can also form and preserve during general humid climatic conditions due to high water table levels (Kocurek and Havholm, 1993; Mountney et al., 1999; Mountney, 2012; Al-Masrahy and Mountney, 2015). Increasing fluctuating humidity is recorded through the middle and late Triassic in the North Sea area (Goldsmith et al. 2003; Preto et al., 2010; Nystuen et al. 2014). Rising and falling water-table levels, reflecting wet and dry periods, respectively, control dune and inter-dune sizes; by rising watertable, inter-dune environment expands, and aeolian sand dune area shrinks, whereas falling water-table has the opposite effect (Mountney and Thompson, 2002; Wakefield, 2019). This pattern has been documented in the Anisian Helsby Sandstone Formation in the Cheshire Basin, England (Mountney and Thompson, 2002). Wet periods in areas with overall aeolian processes lead to fluvial re-transport and re-deposition (Al-Masrahy and Mountney, 2015), as demonstrated in the Etjo Sandstone in Namibia (Mountney et al., 1999; Masrahy and Mountney, 2015). The upward increase in mudstone beds in S4 (Figure 5) may reflect increasing frequency of stable fluvial channels and floodplain fines, in accordance with increasing humidity during late middle to early late Triassic. Intercalation of aeolian and fluvial deposits within S4 is here considered to be controlled by alternation between arid and wet periods; the arid periods controlled the dominance of sand production and aeolian transport and wet periods fluvial sand-recycling and deposition.

\subsection{5 / Sequence 5: tectonics and climate}

The uniformly low thickness across the western and central Horda Platform (Figure 7c) suggests low accommodation during S5 deposition. Wedging, albeit localized, could results from minor renewed faulting along the eastern margin, but can also be attributed to other factors; For example, Müller (2003) explained similar geometric variations in Tampen Spur as post- 
depositional erosion, while Prosser (1993) mentioned wedges occurring in post-rift strata of sediment-starved basins. However, as other studies (e.g. Nøttvedt et al., 1995; Nipen, MSc, 2020) report on a minor middle-Late Triassic rift-stage in other parts of the northern North Sea, this was likely no restricted event.

The fining-upwards and frequent carbonaceous horizons link to changing climatic conditions. Besides increasing humidity through the mid-Late Triassic (Preto et al., 2010), a pronounced wet period in the early-Late Triassic, termed the "Carnian Pluvial Event" (CPE) is known (Mueller et al., 2016). The fine-grained trend in S5 is explained by this, as raising precipitation led to increased runoff and river stabilization by increasing vegetation on floodplains (Prosser, 1993, Corenblit et al., 2015). A knick-point near the hanging-wall of the Smeaheia Fault Block indicate possible fluvial incision (Figure 8). The edges of this may have formed terraces where non-deposition allowed pedogenic processes (Mack et al., 2010; Müller et al. 2004).

\subsection{6 / Sequence 6: climate}

The continuous reflections in S6 indicate a thermally subsiding basin with limited topography or fault segmentation (Figure 10). Thermal subsidence occurred over a wider area with rift axis in (what was later to become) the Viking Graben (Ter Voorde et al., 2000), and the basin took on a saucer-shape, reflected in the westward thickening profile (Figure 3; 7b). This may be a response to the transition from active stretching to thermal cooling and -rebounce, substantiating the common consensus of stratal rotation being redirected towards the basin axis (Nøttvedt et al., 1995). The progradational pattern observed most proximal in S6 may represent fault-scarp derived coarse clastic sediments (Nøttvedt et al., 1995).

Contrasting theories on the lithological changes in S6 include tectonically induced base level changes (e.g. Steel and Ryseth, 1990), and climatic forcing (Frostick et al., 1992; McKie, 2014; Nystuen et al., 2014). Due to lack of growth-features, climatic control is also supported by the present study. Climatic wet/dry fluctuations, like in Eastern Africa during the Plio-Pleistocene (de Boer et al., 2021), can cause significant variations in sedimentation rate and runoff (Strecker et al., 1999). During wet periods, vegetation cover stabilized rivers, increases sinuosity, and promotes fine-grained sediment preservation. In the Sahel-Sahara region, which is at similar latitude to the Triassic North Sea (Coward, 1995), climatic fluctuations are linked to orbital cycles (de Boer et al., 2021), which acted similarly in the Triassic, and may have influenced lake level, as well as sea-level (Vollmer et al., 2008; Chu et al., 2020).

Müller et al. (2004) and Nystuen et al. (2014) found that the fluvial style in the Lunde Formation of Tampen Spur indicates increasing humid climate during late Triassic, giving rise to perennial 
streams and mud-rich floodplains, whereas clay minerals and paleosols in floodplain fines reflect dominating semi-arid conditions, interrupted by more humid intervals. The fluvial style was explained as controlled by high precipitation in upland regions, whereas formation of clay minerals, calcrete and pedogenic features in overbank fines was primarily controlled by arid to semiarid conditions in lowland basin areas. This may also have been the situation during deposition of $\mathrm{S} 6$ in the late Triassic in the Horda Platform.

\section{3 | Rift dynamics}

Two sub-aerial unconformities delimit the Permian-Triassic rift infill in the Horda Platform: the syn-rift unconformity and the post-rift unconformity (sensu Falvey, 1974; Bosence, 1998) (Figure 10). The syn-rift unconformity marks the onset of rifting and separates the pre-rift succession from the initial rift strata. Tilting of the depositional surface results in erosional truncation of the prerift strata, producing an (angular) unconformity, as observed in the Base PT surface (Figure 8). The post-rift unconformity marks the end of rift-constrained basin-fill, here represented by the Base Statfjord Group. While first-order units are bounded by sub-aerial unconformities, lowerorder units are delineated by transgressive surfaces (e.g. Embry, 1995).

\subsection{1 / Incipient rift (Syn-rift stage 1): Sequence 1}

$\mathrm{S} 1$ is defined herein as an incipient rift. The highly heterogeneous accommodation development makes S1 a hybrid between different established rift initiation models. In some models (e.g. Morley, 2002; Matins-Neto and Catuneanu, 2010; Kuchle et al., 2011) rifting starts with the development of large accommodation filled by deep lacustrine facies. Other models (e.g. Leeder and Gawthorpe, 1987; Leeder and Jackson, 1993; Arche and López-Gómez, 1996; Gawthorpe and Leeder, 2000; Jackson et al., 2002; Kinabo et al., 2008; de Almeida et al., 2009; Holz et al., 2014; Holz et al., 2017) argument an onset defined by small, shallow disconnected basins with low subsidence rates, supported by modelling (e.g. Gupta et al., 1998) and subsidence curves from rift basins worldwide (e.g. Moretti and Colletta, 1987; Steckler et al., 1988; Watts et al., 1993; Izart et al., 2003).

Rifting is a progressive and diachronous event, meaning that is may not occur at the same geological time across the rift zone area (Holz et al., 2017). The diachroneity of rift events is reflected in the Base 2 surface, which cannot be defined as an "event-line" as it cuts across riftevent-packages. A potential boundary between an initial- and developed rift is unrecognized and thus negligible when it comes to facies-development and -predictability. A potential rift 
development initiation surface (sensu Holz et al., 2017) would be further down in stratigraphy than Base 2 in the western fault blocks. In its full extension, the Base $S 2$ thus cannot be termed a rift development initiation surface. Therefore, we identify Base 2 as a propagation unconformity, (sensu Bueno, 2004), which is defined as an unconformity created by intra-basinal extension, reflecting the evolutionary diachroneity of a propagating rift.

The drainage trend in the initial rift stage presents another discrepancy in literature. According to Prosser (1993), longitudinal river systems prevail, whereas Gawthorpe and Leeder (2000) and Hemesdaël et al. (2017) states antecedent drainage constitutes the dominating sediment routing. During S1 deposition, longer fault-segments would have experienced longitudinal drainage, but elsewise antecedent drainage is thought to have dominated the early rift system for several reasons; Firstly, the topographic relief in footwall scarps reminiscent erosional gorges induced by antecedent drainage (Figure 6b) (e.g Gawthorpe and Leeder, 2000; Trudgill, 2002; Wise and Noble, 2003; Cowie et al., 2006; Elliot et al., 2012). Secondly, the space between fault segments would have acted as zones of antecedent transport, as these form transverse synclines between the footwall anticlines (Gawthorpe and Hurst, 1993; Schlische, 1995; Sharp et al., 2000; Serck and Braathen, 2019; Williams et al., 2020).

\subsection{2 / Progressive rift (Syn-rift stage 2): Sequence 2}

The widening and deepening accommodation (Figure 7e.2) corresponds to the fault-interaction and linkage stage by Gawthorpe and Leeder (2000), the rift development phase by Holz et al. (2017), and the early rift climax by Prosser (1993). Common to these models is that subsidence outpace sedimentation as depocentres expand and deepen with fault-linkage. Parts of the basin remain in an apparent rift initiation stage with low accommodation, isolated depocentres and segmented faults. However, with the dominantly fine-grained lithology and major part of the basins being in a more mature state relative to S1, S2 reflects a more developed rift, and is therefore termed a "progressive rift" (Figure 10).

\subsection{3 / Rift climax (Syn-rift stage 3): Sequence 3}

The characteristic high variability in seismic facies from footwall to hanging-wall in S3 complies with the Rift climax by Prosser (1993), and the homogeneous depocentre-development and faultlinkage correspond with the Through-going fault stage by Gawthorpe and Leeder (2000) and Fault termination by Holz et al. (2017). S3 is defined rift climax as the stage, relative to the two underlying units, is highly mature in the sense of fault-propagation, depocentre development, and a close-to balanced A/S relationship. The A/S though vary through the succession, reflected by the 
fining- to coarsening-upwards lithological trend. Continental rift basins often exhibit a pulsating pattern of coarsening- and fining-upwards depositional units in syn-rift successions. To account for this, Nøttvedt et al. (1995) (revised by Holz et al., 2017) proposed two models for single- and multi-rift successions: one dedicated to gradually increasing subsidence, while the other illustrates punctuated subsidence with associated intra-rift unconformities, the last one explaining the trends in S3. Similar basin development has been documented by Morley et al. (2007) and Hemelsdaël et al (2017). The maximum rift surface (sensu Holz et al, 2017) in the middle of S3 may represent a transgressive lacustrine surface.

\subsection{4 / Rift termination: Sequence 4}

S4 can be sub-divided in two stages based on the geometric- and lithological trend (Figure 10). The first, coarsening-upwards, stage started in late S3 into S4, while the second stage covers the fining-upwards succession (Figure 5). The first stage corresponds to the rift termination systems tract by Holz et al. (2017), with the slight wedging at the base in the eastern fault block being related to remnant topography from the syn-rift stage (Nøttvedt et al., 1995). The uniformly thick second stage matches the Late Post-rift systems tract by Prosser (1993), while the homogeneous, widespread facies' corresponds to the Fault death stage by Gawthorpe and Leeder (2000) and the Early post-rift sub-stage by Holz et al. (2017). The bounding surfaces of the sequence are supposedly diachronous, as expansion of the channel belt system from the hinterland would be time-transgressive from east to west.

\subsection{5 / Post-rift with local rift initiation: Sequence 5}

The overall thin, fine-grained and fining-upwards Sequence 5 with lateral continuous facies (Figures 4 and 8), reflecting low rate of accommodation and low rate of sedimentation (discussed above), is characteristic of a post-rift phase, as defined by Prosser (1993), Nøttvedt et al. (1995) and Holz et al., (2017). As also discussed above, minor fault movements appear to have taken place, at least locally, during deposition of S5 (Figure 8). Though passive thermal subsidence appears to have been the major mechanism in creation of accommodation for Sequence 5, local fault movements make this stage of the basin evolution a transitional phase from late rift to early post-rift. 


\subsection{6 / Early post-rift: Sequence 6}

Saucer-shaped stratal geometry is common for post-rift basins approaching the passive margin stage (White and McKenzie, 1988), as well as the eastward hanging-wall thickening in the initial part (S6.1; Figure 4), reflecting the passive infill of remaining rift topography (Prosser, 1993). The erosional truncation that caps the prograding reflection package indicates that the Base Statfjord Group represents an unconformity, possibly induced by thermal uplift exceeding extensioninduced isostatic subsidence, resulting in subaerial exposure (Ziegler and Cloetingh, 2004). This boundary is here considered a post-rift unconformity, but different to that of Holz et al. (2017), who defined this as the base of the post-rift succession. Herein, it represents the boundary between early and late post rift (Figure 10). The early post-rift basin was affected by the aftermath of tectonism by filling out the consequent thermal relaxation syneclise with debris eroded from the basin margins. This definition is in fact more comparable to the original Breakaway Unconformity by Bosence (1998), defined as a basin-wide angular unconformity generated at the time of post-rift sedimentation under conditions of thermal subsidence, reflecting the evolution into a passive margin, much like the scenario in the Horda Platform. The early post-rift strata are still continental, possibly with some marine incursions distally, as observed in Late Triassic basinfills in the south-eastern Central North Sea (McKie et al., 2010) and north in the Sogn Graben (Steel and Ryseth, 1990). The late post-rift strata in the study area are horizontally-bedded units above the unconformity, of transgressive deltaic and shallow-marine (Late Triassic-Early Jurassic Statfjord, Dunlin and Brent groups) into deep marine conditions (Middle Jurassic Viking Group) (Ravnås et al., 2000). The possible thin S6 in the Øygarden Fault Zone footwall indicates that S6 deposition locally reached inland over the eastern flank of the basin but was eroded at the basinhinterland transition by the later uplift.

\section{6 | CONCLUSIONS}

This study demonstrates how continental rift successions can be stratigraphically subdivided and correlated by integrating seismic and well log data, exemplified by the Permian-Triassic succession in the Horda Platform. The succession is characterized by continental deposition in eastward-dipping half-graben basins bounded by major N-S striking fault zones. Periodical fault propagation and -linkage, combined with pre-rift topography, exerted the main control on depocentre development, distribution and routing of sediments during rifting. The basin underwent three stages of rifting: from disconnected heterogeneous depocentres with strain concentrated in the west and migrating north, all while gradually expanding and finally reaching a mature half graben state where strain was equally distributed across the Horda Platform. A change from arid to semi-humid climate with strong fluctuations, reflected in distinct shifts in 
sand versus mud-dominated intervals, enhanced and even overprinted the effects of tectonics in the post-rift. These allogenic and autogenic factors induced changes in basin configuration, structurally and sedimentologically, reflected in six gross depositional sequences (S1-S6).

Correlating alluvial sequences deposited in rift basins pose a big challenge as stratigraphic concepts were developed for marine systems in passive margins, where sea-level changes produce correlative flooding surfaces. Classical continental sequence stratigraphic models have been evaluated and revised according to the observations in this study and we propose a best-fit model. The Permian-Triassic succession is bounded at the base by a syn-rift unconformity and at the top by a post-rift unconformity. Internal sequences are delineated by erosional- and transgressive surfaces. The classical models appear more applicable to single half-graben basins as they do not take into account that: (1) strain is a dynamic through time and space; (2) strain distribution and degree at the initiation of rifting is highly dependent on pre-existing structures (e.g. structural lineaments, topography etc.); and (3) tectonostratigraphic boundaries between rift stages are diachronically propagating.

\section{ACKNOWLEDGEMENTS}

Authors thank the Tectonostratigraphic Research Group at the University of Oslo for insightful comments and fruitful discussions during the manuscript maturation. This publication has been produced with support from the NCCS Centre, performed under the Norwegian research program Centres for Environment-friendly Energy Research (FME). The authors acknowledge the following partners for their contributions: Aker Solutions, Ansaldo Energia, Baker Hughes, CoorsTek Membrane Sciences, EMGS, Equinor, Gassco, Krohne, Larvik Shipping, Lundin, Norcem, Norwegian Oil and Gas, Quad Geometrics, Total, Vår Energi, and the Research Council of Norway (257579/E20). Schlumberger is acknowledged for providing academic licenses for the Petrel E\&P

Software Platform, and CGG Services AS and Gassnova AS for providing 3D seismic data. This manuscript has improved from the perceptual reviews of xxx.

\section{REFERENCES}

Abreu, V., Sullivan, M., Pirmez, C., \& Mohrig, D. (2003). Lateral accretion packages (LAPs): an important reservoir element in deep water sinuous channels. Marine and Petroleum Geology, 20(6-8), 631-648.

Al-Masrahy, Mohammed A, \& Mountney, Nigel P. (2015). A classification scheme for fluvial- 
aeolian system interaction in desert-margin settings. Aeolian Research, 17, 67-88.

Anders, M. H., \& Schlische, R. W. (1994). Overlapping faults, intrabasin highs, and the growth of normal faults. The Journal of Geology, 102(2), 165-179.

Andersen, T. B., Jamtveit, B., Dewey, J. F., \& Swensson, E. (1991). Subduction and eduction of continental crust: Major mechanisms during continent-continent collision and orogenic extensional collapse, a model based on the south Norwegian Caledonides. Terra Nova, 3(3), 303-310.

Arche, Alfredo, \& López-Gómez, José (1996). Origin of the Permian-Triassic Iberian Basin, central-eastern Spain. Tectonophysics, 266(1), 443-464.

Bell, R. E., Jackson, C. A. L., Whipp, P. S., \& Clements, B. (2014). Strain migration during multiphase extension: Observations from the northern North Sea. Tectonics, 33(10), 19361963.

Blair, T. C. (1987). Sedimentary processes, vertical stratification sequences, and geomorphology of the Roaring River alluvial fan, Rocky Mountain National Park, Colorado. Journal of Sedimentary Research, 57(1), 1-18.

Blakey, R. C. (1988). Basin tectonics and erg response. Sedimentary Geology, 56(1-4), 127-151.

Bosence, D. W. J. (1998). Stratigraphic and sedimentological models of rift basins. Sedimentation and Tectonics in Rift Basins Red Sea:-Gulf of Aden, 9-25.

Boundy, T. M., Fountain, D. M., \& Austrheim, H. (1992). Structural development and petrofabrics of eclogite facies shear zones, Bergen Arcs, western Norway: implications for deep crustal deformational processes. Journal of Metamorphic Geology, 10(2), 127-146.

Bourquin, S., Guillocheau, F., \& Péron, S. (2009). Braided rivers within an arid alluvial plain (example from the Lower Triassic, western German Basin): recognition criteria and expression of stratigraphic cycles. Sedimentology, 56(7), 2235-2264.

Bourquin, Sylvie, Bercovici, Antoine, López-Gómez, José, Diez, José B, Broutin, Jean, Ronchi, Ausonio, Durand, Marc, Arché, Alfredo, Linol, Bastien, \& Amour, Frédéric. (2011). The Permian-Triassic transition and the onset of Mesozoic sedimentation at the northwestern peri-Tethyan domain scale: Palaeogeographic maps and geodynamic implications. Palaeogeography, Palaeoclimatology, Palaeoecology, 299(1-2), 265-280.

Bridge, J. S., \& Tye, R. S. (2000). Interpreting the dimensions of ancient fluvial channel bars, channels, and channel belts from wireline-logs and cores. AAPG bulletin, 84(8), 1205-1228.

Braathen, A., Osmundsen, P. T., Nordgulen, Ø., Roberts, D., \& Meyer, G. B. (2002). Orogen-parallel extension of the Caledonides in northern Central Norway: an overview. Norwegian Journal of Geology/Norsk Geologisk Forening, 82(4).

Bueno, G. V. (2004). Diacronismo de eventos no rifte Sul-Atlântico. Boletim de Geociências da Petrobras, Rio de Janeiro, 12(2), 203-229.

Catuneanu, 0. (2006). Principles of sequence stratigraphy. Elsevier.

Catuneanu, O., Abreu, V., Bhattacharya, J. P., Blum, M. D., Dalrymple, R. W., Eriksson, P. G., ... \& Winker, C. (2009). Towards the standardization of sequence stratigraphy. Earth-Science Reviews, 92(1-2), 1-33.

Christiansson, P., Faleide, J. I., \& Berge, A. M. (2000). Crustal structure in the northern North Sea: an integrated geophysical study. Geological Society, London, Special Publications, 167(1), $15-40$.

Chu, R., Wu, H., Zhu, R., Fang, Q., Deng, S., Cui, J., ... \& Zhang, S. (2020). Orbital forcing of Triassic megamonsoon activity documented in lacustrine sediments from Ordos Basin, China. Palaeogeography, Palaeoclimatology, Palaeoecology, 541, 109542.

Chumakov, N. M., \& Zharkov, M. A. (2003). Climate during the Permian-Triassic biosphere 
reorganizations. Article 2. Climate of the Late Permian and Early Triassic: general inferences. Stratigraphy and Geological Correlation, 11(4), 361-375.

Copestake, P., Sims, A., Crittenden, A., Hamar, G., Rose, P. and Tringham, M. (2003). Lower Cretaceous. In: The Millennium Atlas: Petroleum Geology of the Central and Northern North Sea. The Geological Society of London, pp. 191-211.

Corenblit, D., Davies, N. S., Steiger, J., Gibling, M. R., \& Bornette, G. (2015). Considering river structure and stability in the light of evolution: feedbacks between riparian vegetation and hydrogeomorphology. Earth Surface Processes and Landforms, 40(2), 189-207.

Coward, M. P. (1995). Structural and tectonic setting of the Permo-Triassic basins of northwest Europe. Geological Society, London, Special Publications, 91(1), 7-39.

Coward, M.P., Dewey, J., Hempton, M. \& Holroyd, J. 2003. Tectonic evolution. In: Evans, D. (ed.) The Millennium Atlas: Petroleum Geology of the Central and Northern North Sea. Geological Society, London, 17-33.

Cowie, P. A., Underhill, J. R., Behn, M. D., Lin, J., \& Gill, C. E. (2005). Spatio-temporal evolution of strain accumulation derived from multi-scale observations of Late Jurassic rifting in the northern North Sea: A critical test of models for lithospheric extension. Earth and Planetary Science Letters, 234(3-4), 401-419.

Cowie, P. A., Attal, M., Tucker, G. E., Whittaker, A. C., Naylor, M., Ganas, A., \& Roberts, G. P. (2006). Investigating the surface process response to fault interaction and linkage using a numerical modelling approach. Basin Research, 18(3), 231-266.

de Almeida, R. P., Janikian, L., Fragoso-Cesar, A. R. S., \& Marconato, A. (2009). Evolution of a rift basin dominated by subaerial deposits: The Guaritas Rift, Early Cambrian, Southern Brazil. Sedimentary Geology, 217(1-4), 30-51.

de Boer, B., Peters, M., \& Lourens, L. J. (2021). The transient impact of the African monsoon on Plio-Pleistocene Mediterranean sediments. Climate of the Past, 17(1), 331-344.

Dolson, J. C., Bahorich, M. S., Tobin, R. C., Beaumont, E. A., Terlikoski, L. J., Hendricks, M. L., \& Foster, N. H. (1999). Exploring for stratigraphic traps. Exploring for oil and gas traps: AAPG Treatise of Petroleum Geology, Handbook of Petroleum Geology, 21-1.

Duffy, O. B., Bell, R. E., Jackson, C. A. L., Gawthorpe, R. L., \& Whipp, P. S. (2015). Fault growth and interactions in a multiphase rift fault network: Horda Platform, Norwegian North Sea. Journal of Structural Geology, 80, 99-119.

Elliott, G. M., Wilson, P., Jackson, C. A. L., Gawthorpe, R. L., Michelsen, L., \& Sharp, I. R. (2012). The linkage between fault throw and footwall scarp erosion patterns: an example from the Bremstein Fault Complex, offshore Mid-Norway. Basin Research, 24(2), 180-197.

Embry, A. F. (1995). Sequence boundaries and sequence hierarchies: problems and proposals. In Norwegian Petroleum Society Special Publications (Vol. 5, pp. 1-11). Elsevier.

Evans, D., Graham, C. and Bathurst, P. (Eds) (2003). Millenium Atlas: Petroleum Geology of the Central and Northern North Sea. A project of the Geological Society of London, the Geological Survey of Denmark and Greenland and the Norwegian Petroleum Society.

Faleide, J. I., Kyrkjebo, R., Kjennerud, T., Gabrielsen, R. H., Jordt, H., Fanavoll, S., \& Bjerke, M. D. (2002). Tectonic impact on sedimentary processes during Cenozoic evolution of the northern North Sea and surrounding areas. Special Publication-Geological Society of London, 196, 235-270.

Falvey, D. A. (1974). The development of continental margins in plate tectonic theory. The APPEA Journal, 14(1), 95-106.

Fazlikhani, H., Fossen, H., Gawthorpe, R. L., Faleide, J. I., \& Bell, R. E. (2017). Basement structure 
and its influence on the structural configuration of the northern North Sea rift. Tectonics, 36(6), 1151-1177.

Fossen, H. (1992). The role of extensional tectonics in the Caledonides of south Norway. Journal of structural geology, 14(8-9), 1033-1046.

Fossen, H., Khani, H. F., Faleide, J. I., Ksienzyk, A. K., \& Dunlap, W. J. (2017). Post-Caledonian extension in the West Norway-northern North Sea region: the role of structural inheritance. Geological Society, London, Special Publications, 439(1), 465-486.

Fraser, S., Robinson, A., Johnson, H., Underhill, J. and Kadolsky, D. (2003). Upper Jurassic. In: The Millennium Atlas: Petroleum Geology of the Central and Northern North Sea. The Geological Society of London, pp. 157-189.

Frostick, L., Reid, I., Jarvis, J. T., \& Eardley, H. (1988). Triassic sediments of the Inner Moray Firth, Scotland: early rift deposits. Journal of the Geological Society, 145(2), 235-248.

Frostick, L. E., Linsey, T. K., \& Reid, I. (1992). Tectonic and climatic control of Triassic sedimentation in the Beryl Basin, northern North Sea.Journal of the Geological Society, 149(1), 13-26.

Furre, A., Bakke, R., \& Ringrose, P. (2018, November). Feasibility Of Permanent Seismic Monitoring Of A CO2 Storage Site Offshore Norway. In Fifth CO2 Geological Storage Workshop (Vol. 2018, No. 1, pp. 1-5). European Association of Geoscientists \& Engineers.

Færseth, R. B. (1996). Interaction of Permo-Triassic and Jurassic extensional fault-blocks during the development of the northern North Sea. Journal of the Geological Society, 153(6), 931944.

Færseth, R. B., Gabrielsen, R. H., \& Hurich, C. A. (1995). Influence of basement in structuring of the North Sea basin, offshore southwest Norway. Norsk Geologisk Tidsskrift, 75(2-3), 105119.

Gabrielsen, R. H., Kyrkjebø, R., Faleide, J. I., Fjeldskaar, W., \& Kjennerud, T. (2001). The Cretaceous post-rift basin configuration of the northern North Sea. Petroleum Geoscience, 7(2), 137154.

Gawthorpe, R. L., \& Hurst, J. M. (1993). Transfer zones in extensional basins: their structural style and influence on drainage development and stratigraphy. Journal of the Geological Society, 150(6), 1137-1152.

Gawthorpe, R. L., Fraser, A. J., \& Collier, R. E. L. (1994). Sequence stratigraphy in active extensional basins: implications for the interpretation of ancient basin-fills. Marine and petroleum geology, 11(6), 642-658.

Gawthorpe, R. L., \& Leeder, M. R. (2000). Tectono-sedimentary evolution of active extensional basins. Basin Research, 12(3-4), 195-218.

Gee, D. G., Andreasson, P. G., Lorenz, H., Frei, D., \& Majka, J. (2015). Detrital zircon signatures of the Baltoscandian margin along the Arctic Circle Caledonides in Sweden: The Sveconorwegian connection. Precambrian Research, 265, 40-56.

Goldsmith, P.J., Hudson, G. and Van Veen, P (2003). Triassic. In: The Millennium Atlas: Petroleum Geology of the Central and Northern North Sea. The Geological Society of London, pp. 105127.

Gupta, Sanjeev, Cowie, Patience A, Dawers, Nancye H, \& Underhill, John R. (1998). A mechanism to explain rift-basin subsidence and stratigraphic patterns through fault-array evolution. Geology (Boulder), 26(7), 595-598.

Heeremans, M., \& Faleide, J. I. (2004). Late Carboniferous-Permian tectonics and magmatic activity in the Skagerrak, Kattegat and the North Sea. Geological Society, London, Special Publications, 223(1), 157-176. 
Hemelsdaël, R., Ford, M., Malartre, F., \& Gawthorpe, R. (2017). Interaction of an antecedent fluvial system with early normal fault growth: Implications for syn-rift stratigraphy, western Corinth rift (Greece). Sedimentology, 64(7), 1957-1997.

Holz, Michael, Troccoli, Edric, \& Vieira, Marcelo. (2014). Sequence Stratigraphy of Continental Rift Basins I: A Conceptual Discussion of Discrepant Models. In STRATI 2013 (pp. 9-13). Springer International Publishing

Holz, M., Vilas-Boas, D. B., Troccoli, E. B., Santana, V. C., \& Vidigal-Souza, P. A. (2017). Conceptual models for sequence stratigraphy of continental rift successions. In Stratigraphy \& Timescales (Vol. 2, pp. 119-186). Academic Press.

Howell, J., \& Mountney, N. (1997). Climatic cyclicity and accommodation space in arid to semi-" arid depositional systems: an example from the Rotliegend Group of the UK southern North Sea. Geological Society, London, Special Publications, 123(1), 63-86.

Husmo, T., Hamar, G. P., Høiland, O., Johannessen, E. P., Rømuld, A., Spencer, A. and Titterton, R. (2003). Lower and middle Jurassic. In: The Millennium Atlas: Petroleum Geology of the Central and Northern North Sea. The Geological Society of London, pp. 129-155.

Izart, Alain, Stephenson, Randell, Vai, Gian Battista, Vachard, Daniel, Le Nindre, Yves, Vaslet, Denis, Fauvel, Pierre-Jean, Süss, Peter, Kossovaya, Olga, Chen, Zhongquiang, Maslo, Alexander, \& Stovba, Serguei. (2003). Sequence stratigraphy and correlation of late Carboniferous and Permian in the CIS, Europe, Tethyan area, North Africa, Arabia, China, Gondwanaland and the USA. Palaeogeography, Palaeoclimatology, Palaeoecology, 196(1), 59-84.

Jackson, C. A. L., Gawthorpe, R. L., \& Sharp, I. R. (2002). Growth and linkage of the East Tanka fault zone, Suez rift: structural style and syn-rift stratigraphic response. Journal of the Geological Society, 159(2), 175-187.

Jarsve, E. M., Maast, T. E., Gabrielsen, R. H., Faleide, J. I., Nystuen, J. P., \& Sassier, C. (2014). Seismic stratigraphic subdivision of the Triassic succession in the Central North Sea; integrating seismic reflection and well data. Journal of the Geological Society, 171(3), 353-374.

Kinabo, B. D., Hogan, J. P., Atekwana, E. A., Abdelsalam, M. G., \& Modisi, M. P. (2008). Fault growth and propagation during incipient continental rifting: Insights from a combined aeromagnetic and Shuttle Radar Topography Mission digital elevation model investigation of the Okavango Rift Zone, northwest Botswana. Tectonics, 27(3).

Kjemperud, A.V. (2008) Sequence stratigraphy of alluvial successions: depositional style and controlling factors. Ph.D. Thesis, Department of Geosciences, University of Oslo, Norway, 270 pp. Unpublished.

Kocurek, G., \& Havholm, K. G. (1993). Eolian Sequence Stratigraphy - A Conceptual Framework: Chapter 16: Recent Developments in Siliciclastic Sequence Stratigraphy. AAPG Special Volume (1993), 393-409.

Kombrink, H., \& Patruno, S. (2020). The integration of public domain lithostratigraphic data into a series of cross-border North Sea well-penetration maps. Geological Society, London, Special Publications, 494.

Korte, C., Kozur, H. W., \& Veizer, J. (2005). $\delta 13 \mathrm{C}$ and $\delta 180$ values of Triassic brachiopods and carbonate rocks as proxies for coeval seawater and palaeotemperature. Palaeogeography, Palaeoclimatology, Palaeoecology, 226(3-4), 287-306.

Kraus, M. J. (1999). Paleosols in clastic sedimentary rocks: Their geologic applications. Earth Science Reviews, 47(1), 41-70.

Kuchle, Juliano, Scherer, Claiton Marlon dos Santos, Born, Christian Correa, Alvarenga, Renata 
dos Santos, \& Adegas, Felipe. (2011). A contribution to regional stratigraphic correlations of the Afro-Brazilian depression - The Dom João Stage (Brotas Group and equivalent units - Late Jurassic) in Northeastern Brazilian sedimentary basins. Journal of South American Earth Sciences, 31(4), 358-371.

Lambiase, J.J, \& Bosworth, W. (1995). Structural controls on sedimentation in continental rifts. Geological Society, London, Special Publications, 80(1), 117-144.

Leeder, M. R, \& Gawthorpe, R. L. (1987). Sedimentary models for extensional tilt-block/halfgraben basins. Geological Society, London, Special Publications, 28(1), 139-152.

Leeder, M. R., \& Jackson, J. A. (1993). The interaction between normal faulting and drainage in active extensional basins, with examples from the western United States and central Greece. Basin research, 5(2), 79-102.

Lenhart, A., Jackson, C. A. L., Bell, R. E., Duffy, O. B., Gawthorpe, R. L., \& Fossen, H. (2019). Structural architecture and composition of crystalline basement offshore west Norway. Lithosphere, 11(2), 273-293.

Lervik, K. (2006). Triassic lithostratigraphy of the northern North Sea Basin. Norsk Geologisk Tidsskrift, 86(2), 93.

Mack, G. H., Tabor, N. J., \& Zollinger, H. J. (2010). Palaeosols and sequence stratigraphy of the Lower Permian Abo Member, south-central New Mexico, USA. Sedimentology, 57(6), 1566-1583.

Marshall, J. E. A., \& Hewett, A. J. (2003). Devonian. Geological Society of London.

Martins-Neto, M. A., \& Catuneanu, O. (2010). Rift sequence stratigraphy. Marine and Petroleum Geology, 27(1), 247-253.

McKie, T. (2014). Climatic and tectonic controls on Triassic dryland terminal fluvial system architecture, central North Sea. From Depositional Systems to Sedimentary Successions on the Norwegian Continental Margin (eds Martinius AW, Ravn R., Howell JA, Steel RJ \& Wonham JP), 19-58.

McKie, T., \& Williams, B. (2009). Triassic paleogeography and fluvial dispersal across the northwest European Basins. Geological Journal, 44(6), 711-741.

McKie, T., Jolley, S. J., \& Kristensen, M. B. (2010). Stratigraphic and structural compartmentalization of dryland fluvial reservoirs: Triassic Heron Cluster, Central North Sea. Geological Society, London, Special Publications, 347(1), 165-198.

Miall, A. (2010). Alluvial Deposits. In James, N., \& Dalrymple, R. (2010): Facies models : 4 (Vol. 6, Geotext). St. Johns's, Nfld: Geological Association of Canada.

Mitten, A. J., Howell, L. P., Clarke, S. M., \& Pringle, J. K. (2020). Controls on the deposition and preservation of architectural elements within a fluvial multi-storey sandbody. Sedimentary Geology, 401, 105629.

Moretti, I, \& Colletta, B. (1987). Spatial and temporal evolution of the Suez rift subsidence. Journal of Geodynamics, 7(1), 151-168.

Morley, C. K. (2002). Evolution of large normal faults: Evidence from seismic reflection data. AAPG bulletin, 86(6), 961-978.

Morley, C.K, Gabdi, S, \& Seusutthiya, K. (2007). Fault superimposition and linkage resulting from stress changes during rifting: Examples from 3D seismic data, Phitsanulok Basin, Thailand. Journal of Structural Geology, 29(4), 646-663.

Moscariello, A. (2018). Alluvial fans and fluvial fans at the margins of continental sedimentary basins: Geomorphic and sedimentological distinction for geo-energy exploration and development. Geological Society Special Publication, 440(1), 215-243.

Mountney, Nigel, Howell, John, Flint, Stephen, \& Jerram, Dougal. (1999). Climate, sediment supply 
and tectonics as controls on the deposition and preservation of the aeolian-fluvial Etjo Sandstone Formation, Namibia. Journal of the Geological Society, 156(4), 771-777.

Mountney, N. P., \& Thompson, D. B. (2002). Stratigraphic evolution and preservation of aeolian dune and damp/wet interdune strata: an example from the Triassic Helsby Sandstone Formation, Cheshire Basin, UK. Sedimentology, 49(4), 805-833.

Mountney, N. P. (2012). A stratigraphic model to account for complexity in aeolian dune and interdune successions. Sedimentology, 59(3), 964-989.

Mueller, S., Hounslow, M. W., \& Kürschner, W. M. (2016). Integrated stratigraphy and palaeoclimate history of the Carnian Pluvial Event in the Boreal realm; new data from the Upper Triassic Kapp Toscana Group in central Spitsbergen (Norway). Journal of the Geological Society, 173(1), 186-202.

Müller, R. (2003). Basin fill dynamics and alluvial architecture of the Permo-Triassic, northern North Sea [unpublished manuscript from doctoral dissertation]. University of Oslo

Müller, R., Nystuen, J. P., \& Wright, V. P. (2004). Pedogenic mud aggregates and paleosol development in ancient dryland river systems: criteria for interpreting alluvial mudrock origin and floodplain dynamics. Journal of Sedimentary Research, 74(4), 537-551.

Mulrooney, M.J., Osmond, J.L., Skurtveit, E., Faleide, J.I. \& Braathen, A. (2020). Structural analysis of the Smeaheia fault block, a potential $\mathrm{CO}_{2}$ storage site, northern Horda Platform, North Sea. Marine and Petroleum Geology

Neumann, E. R., Wilson, M., Heeremans, M., Spencer, E. A., Obst, K., Timmerman, M. J., \& Kirstein, L. (2004). Carboniferous-Permian rifting and magmatism in southern Scandinavia, the North Sea and northern Germany: a review. Geological Society, London, Special Publications, 223(1), 11-40.

Nipen, H. (2020). Permo-Triassic Basin development in the Horda Platform and Stord Basin. M.Sc. Thesis. University of Oslo. Unpublished.

Norsk Hydro Produksjon (1984). Final Well Report, Well 31/6-1. Norsk Hydro Produksjon.

Nystuen, J. P., Knarud, R., Jorde, K., \& Stanley, K. O. (1989). Correlation of Triassic to Lower Jurassic sequences, Snorre field and adjacent areas, northern North Sea. In Correlation in Hydrocarbon Exploration (pp. 273-289). Springer, Dordrecht.

Nystuen, J. P., \& Fält, L. M. (1995). Upper Triassic-Lower Jurassic reservoir rocks in the Tampen Spur area, Norwegian North Sea. In Norwegian Petroleum Society Special Publications(Vol. 4, pp. 135-179). Elsevier.

Nystuen, J. P., Kjemperud, A. V., Müller, R., Adestål, V., \& Schomacker, E. R. (2014). Late Triassic to Early Jurassic climatic change, northern North Sea region: impact on alluvial architecture, paleosols and clay mineralogy. From Depositional Systems to Sedimentary Successions on the Norwegian Continental Margin, 59-99.

Nøttvedt, A., Gabrielsen, R. H., \& Steel, R. J. (1995). Tectonostratigraphy and sedimentary architecture of rift basins, with reference to the northern North Sea. Marine and Petroleum Geology, 12(8), 881-901.

Odinsen, T., Reemst, P., Van Der Beek, P., Faleide, J. I., \& Gabrielsen, R. H. (2000a). Permo-Triassic and Jurassic extension in the northern North Sea: results from tectonostratigraphic forward modelling. Geological Society, London, Special Publications, 167(1), 83-103.

Odinsen, T., Christiansson, P., Gabrielsen, R. H., Faleide, J. I., \& Berge, A. M. (2000b). The geometries and deep structure of the northern North Sea rift system. Geological Society, London, Special Publications, 167(1), 41-57.

Olaka, L. A., Odada, E. O., Trauth, M. H., \& Olago, D. O. (2010). The sensitivity of East African rift lakes to climate fluctuations. Journal of Paleolimnology, 44(2), 629-644. 
Osmundsen, P. T., \& Andersen, T. B. (2001). The middle Devonian basins of western Norway: sedimentary response to large-scale transtensional tectonics?. Tectonophysics, 332(1-2), 51-68.

Peacock, D. C. P., \& Sanderson, D. J. (1994). Geometry and development of relay ramps in normal fault systems. AAPG bulletin, 78(2), 147-165.

Pegrum, R. M., \& Spencer, A. M. (1990). Hydrocarbon plays in the northern North Sea. Geological Society, London, Special Publications, 50(1), 441-470.

Phillips, T. B., Fazlikhani, H., Gawthorpe, R. L., Fossen, H., Jackson, C. A. L., Bell, R. E., ... \& Rotevatn, A. (2019). The Influence of Structural Inheritance and Multiphase Extension on Rift Development, the Northern North Sea. Tectonics, 38(12), 4099-4126.

Phillips Petroleum Company Norway (1996). PL 205 Licence Group, Well 32/4-1, Final Well Report. Philips Petroleum Company Norway.

Posamentier, H. W., \& Vail, P. R. (1988). Eustatic controls on clastic deposition II-sequence and systems tract models.

Preto, Nereo, Kustatscher, Evelyn, \& Wignall, Paul B. (2010). Triassic climates - State of the art and perspectives. Palaeogeography, Palaeoclimatology, Palaeoecology, 290(1), 1-10.

Prosser, S. (1993). Rift-related linked depositional systems and their seismic expression. Geological Society, London, Special Publications, 71(1), 35-66.

Ravnås, R., Nøttvedt, A., Steel, R. J., \& Windelstad, J. (2000). Syn-rift sedimentary architectures in the Northern North Sea. Geological Society, London, Special Publications, 167(1), 133-177.

Rhee, C. W. (2006). Conceptual problems and recent progress in fluvial sequence stratigraphy. Geosciences Journal, 10(4), 433-443.

Riber, L., Dypvik, H., \& Sørlie, R. (2015). Altered basement rocks on the Utsira High and its surroundings, Norwegian North Sea. Norwegian Journal of Geology, 95(1), 57-89.

Roberts, A. M., Yielding, G., Kusznir, N. J., Walker, I. M., \& Dorn-Lopez, D. (1995). Quantitative analysis of Triassic extension in the northern Viking Graben. Journal of the Geological Society, 152(1), 15-26.

Roberts, D. (2003). The Scandinavian Caledonides: event chronology, palaeogeographic settings and likely modern analogues. Tectonophysics, 365(1-4), 283-299.

Rodríguez-López, J. P., Clemmensen, L. B., Lancaster, N., Mountney, N. P., \& Veiga, G. D. (2014). Archean to Recent aeolian sand systems and their sedimentary record: current understanding and future prospects. Sedimentology, 61(6), 1487-1534.

Roksandić, M. M. (1978). Seismic facies analysis concepts. Geophysical Prospecting, 26(2), 383398.

Røe, S. L., \& Steel, R. (1985). Sedimentation, sea-level rise and tectonics at the Triassic-Jurassic boundary (Statfjord Formation), Tampen Spur, northern North Sea. Journal of Petroleum Geology, 8(2), 163-186.

Schlische, R. W. (1995). Geometry and Origin of Fault-Related Folds in Extensional Settings. AAPG Bulletin, 79.

Schlische, R. W., \& Anders, M. H. (1996). Stratigraphic effects and tectonic implications of the growth of normal faults and extensional basins. Special Papers - Geological Society of America, 183-203.

Schlische, R. W., \& Olsen, P. E. (1990). Quantitative filling model for continental extensional basins with applications to early Mesozoic rifts of eastern North America. The Journal of Geology, 98(2), 135-155.

Schomacker, E.R. (2008) Geological reservoir characterization of alluvial deposits: architectural 
style and variability. Ph.D. Thesis, Department of Geosciences, University of Oslo, Norway, 262 pp. Unpublished.

Schwab, A. M., Cronin, B. T., \& Ferreira, H. (2007). Seismic expression of channel outcrops: Offset stacked versus amalgamated channel systems. Marine and Petroleum Geology, 24(6-9), 504-514.

Shanley, K. W., \& McCabe, P. J. (1994). Perspectives on the sequence stratigraphy of continental strata. AAPG bulletin, 78(4), 544-568.

Sharp, Ian R, Gawthorpe, Rob L, Underhill, John R, \& Gupta, Sanjeev. (2000). Fault-propagation folding in extensional settings: Examples of structural style and synrift sedimentary response from the Suez rift, Sinai, Egypt. Geological Society of America Bulletin, 112(12), 1877-1899..

Serck, C. S., \& Braathen, A.. (2019). Extensional fault and fold growth: Impact on accommodation evolution and sedimentary infill. Basin Research, 31(5), 967-990.

Spencer, A. M., \& Larsen, V. B. (1990). Fault traps in the northern North Sea. Geological Society, London, Special Publications, 55(1), 281-298.

Steckler, Michael S, Berthelot, François, Lyberis, Nicolas, \& Le Pichon, Xavier. (1988). Subsidence in the gulf of suez: implications for rifting and plate kinematics. Tectonophysics, 153(1), 249-270.

Steel, R. J. (1993). Triassic-Jurassic megasequence stratigraphy in the Northern North Sea: rift to post-rift evolution. In Geological Society, London, Petroleum Geology Conference series (Vol. 4, No. 1, pp. 299-315). Geological Society of London.

Steel, R., \& Ryseth, A. (1990). The Triassic-Early Jurassic succession in the northern North Sea: megasequence stratigraphy and intra-Triassic tectonics. Geological Society, London, Special Publications, 55(1), 139-168.

Strecker, U., Steidtmann, J. R., \& Smithson, S. B. (1999). A conceptual tectonostratigraphic model for seismic facies migrations in a fluvio-lacustrine extensional basin. AAPG bulletin, 83(1), 43-61.

Surlyk, F., Dons, T., Clausen, C. K. and Higham, J. (2003). Upper Cretaceous. In: The Millennium Atlas: Petroleum Geology of the Central and Northern North Sea. The Geological Society of London, pp. 213-233.

Ter Voorde, M., Færseth, R. B., Gabrielsen, R. H., \& Cloetingh, S. A. P. L. (2000). Repeated lithosphere extension in the northern Viking Graben: a coupled or a decoupled rheology?. Geological Society, London, Special Publications, 167(1), 59-81.

Trudgill, B.D. (2002) Structural controls on drainage development in the Canyonlands grabens of southeast Utah. AAPG Bull., 86, 1095-1112.

Underhill, J. R., \& Partington, M. A. (1993). Jurassic thermal doming and deflation in the North Sea: implications of the sequence stratigraphic evidence. In Geological Society, London, Petroleum Geology Conference series (Vol. 4, No. 1, pp. 337-345). Geological Society of London.

Van Wagoner, J. C., Posamentier, H. W., Mitchum, R. M. J., Vail, P. R., Sarg, J. F., Loutit, T. S., \& Hardenbol, J. (1988). An overview of the fundamentals of sequence stratigraphy and key definitions.

Verschuren, D. (1999). Sedimentation controls on the preservation and time resolution of climate-proxy records from shallow fluctuating lakes. Quaternary Science Reviews, 18(6), 821-837.

Vollmer, T., Werner, R., Weber, M., Tougiannidis, N., Röhling, H. G., \& Hambach, U. (2008). Orbital 
control on Upper Triassic Playa cycles of the Steinmergel-Keuper (Norian): A new concept for ancient playa cycles. Palaeogeography, Palaeoclimatology, Palaeoecology, 267(1-2), 116.

Vollset, J., \& Doré, A. G. (Eds.). (1984). A revised Triassic and Jurassic lithostratigraphic nomenclature for the Norwegian North Sea. Oljedirektoratet.

Wakefield, O. (2019). The importance of water in aeolian systems: an example from the Sherwood Sandstone of the West Midlands. Proceedings of the Open University Geological Society, 5, 81-84.

Walker, R. G. (1976). Facies model-3. Sandy fluvial systems. Geoscience Canada.

Watts, A. B, Piatt, J. P, \& Buhl, P. (1993). Tectonic evolution of the Alboran Sea basin. Basin Research, 5(3), 153-177.

Whipp, P. S., Jackson, C. L., Gawthorpe, R. L., Dreyer, T., \& Quinn, D. (2014). Normal fault array evolution above a reactivated rift fabric; a subsurface example from the northern Horda Platform, Norwegian North Sea. Basin Research, 26(4), 523-549.

White, N., \& McKenzie, D. (1988). Formation of the" steer's head" geometry of sedimentary basins by differential stretching of the crust and mantle. Geology, 16(3), 250-253.

Williams, R. M., Underhill, J. R., \& Jamieson, R. J. (2020). The role of relay ramp evolution in governing sediment dispersal and petroleum prospectivity of syn-rift stratigraphic plays in the Northern North Sea. Petroleum Geoscience, 26(2), 232-246.

Wise, J. M., \& Noble, D. C. (2003). Geomorphic evolution of the Cordillera Blanca, northern Peru. Boletin de la sociedad Geologica del Peru, 96, 65-85.

Withjack, M. O., Schlische, R. W., \& Olsen, P. E. (2002). Rift-basin structure and its influence on sedimentary systems.

Zanella, E., Coward, M. P., \& McGrandle, A. (2003). Crustal structure. In: The Millennium Atlas: Petroleum Geology of the Central and Northern North Sea. The Geological Society of London, pp. 35-43.

Ziegler, P.A. (1992). North Sea rift system, Tectonophysics, 208(1-3), pp 55-75.

Ziegler, P. A., \& Cloetingh, S. (2004). Dynamic processes controlling evolution of rifted basins. Earth-Science Reviews, 64(1-2), 1-50. 


\section{FIGURES}

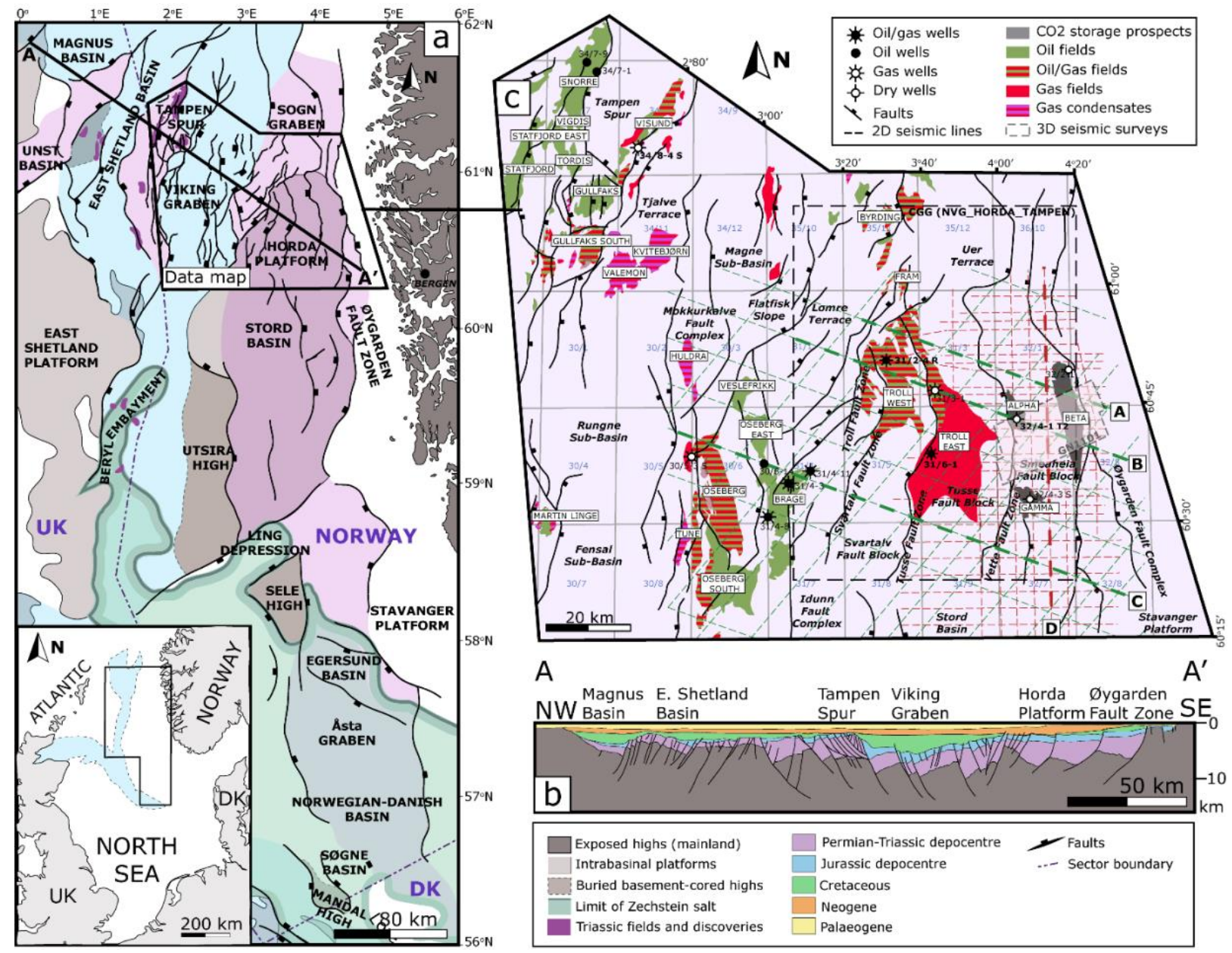

FIGURE 1 a) Map of the northern North Sea showing the location of the study area (outlined in black) with main structural elements. The Permo-Triassic depocenter is highlighted in purple, while the blue shade marks the Jurassic. b) Cross-section through the study area. Modified from Færseth (1996). c) Quadrant map of the greater study area, including the Horda Platform extending across the northern Viking Graben (Tjalve Terrace, Rungne Sub-Basin and Fensal Sub-Basin) into the Tampen Spur area with hydrocarbon fields and faults. The extend of seismic data coverage is marked along with all wells included in the study. 


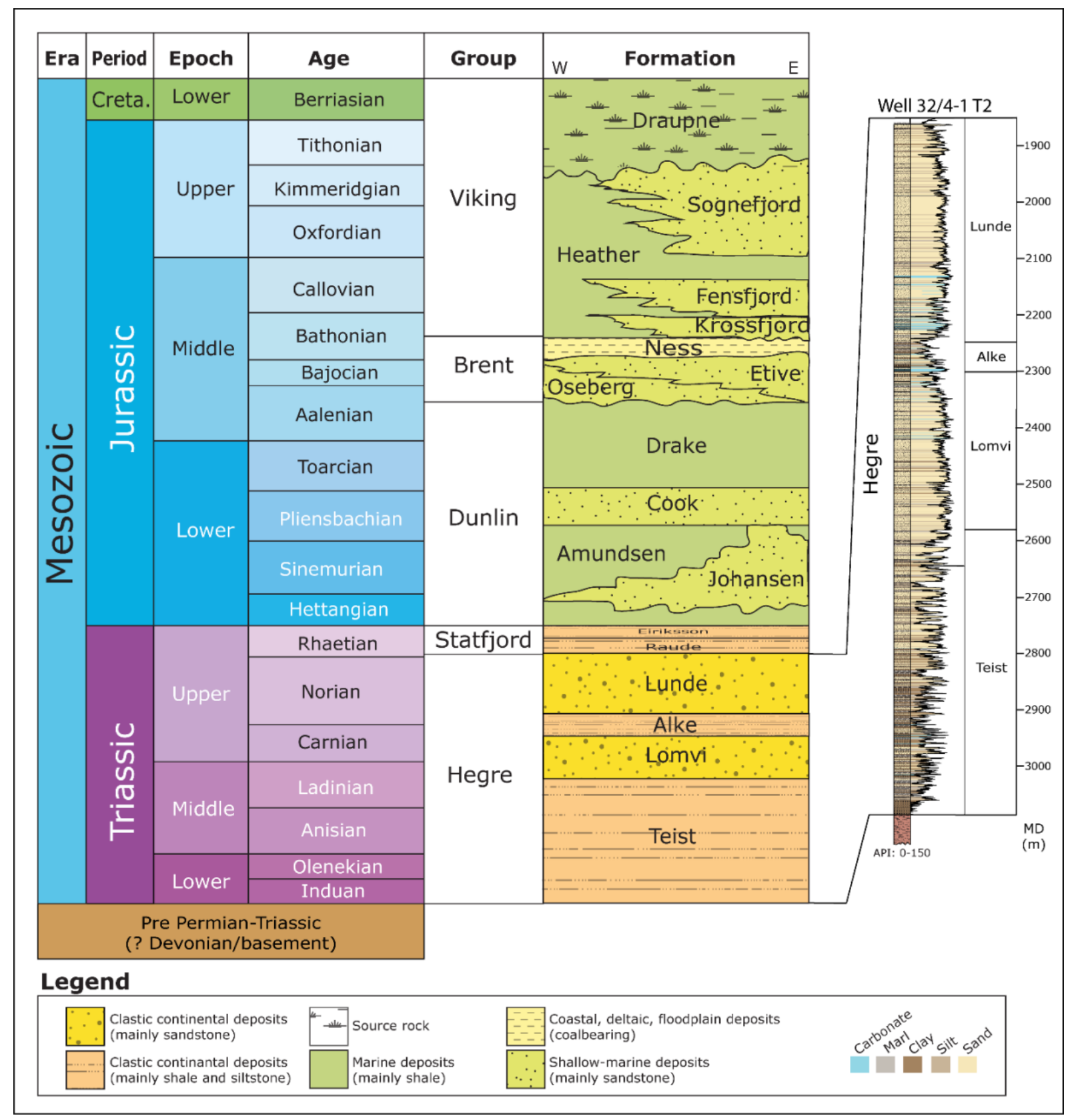

FIGURE 2 Stratigraphic scheme for the Hegre Group in the northern Horda Platform, northern North Sea. Lithostratigraphy is illustrated with a gamma-ray log from well 32/4-1 (Smeaheia Fault Block) with true stratigraphic thickness in metres. The well-log features an interpretation of lithology presented in coloration from brown (clay) and tan (silt) to light yellow (sand) and blue (carbonate). The applied stratigraphic nomenclature is in accordance with the revised scheme by Lervik (2006). 


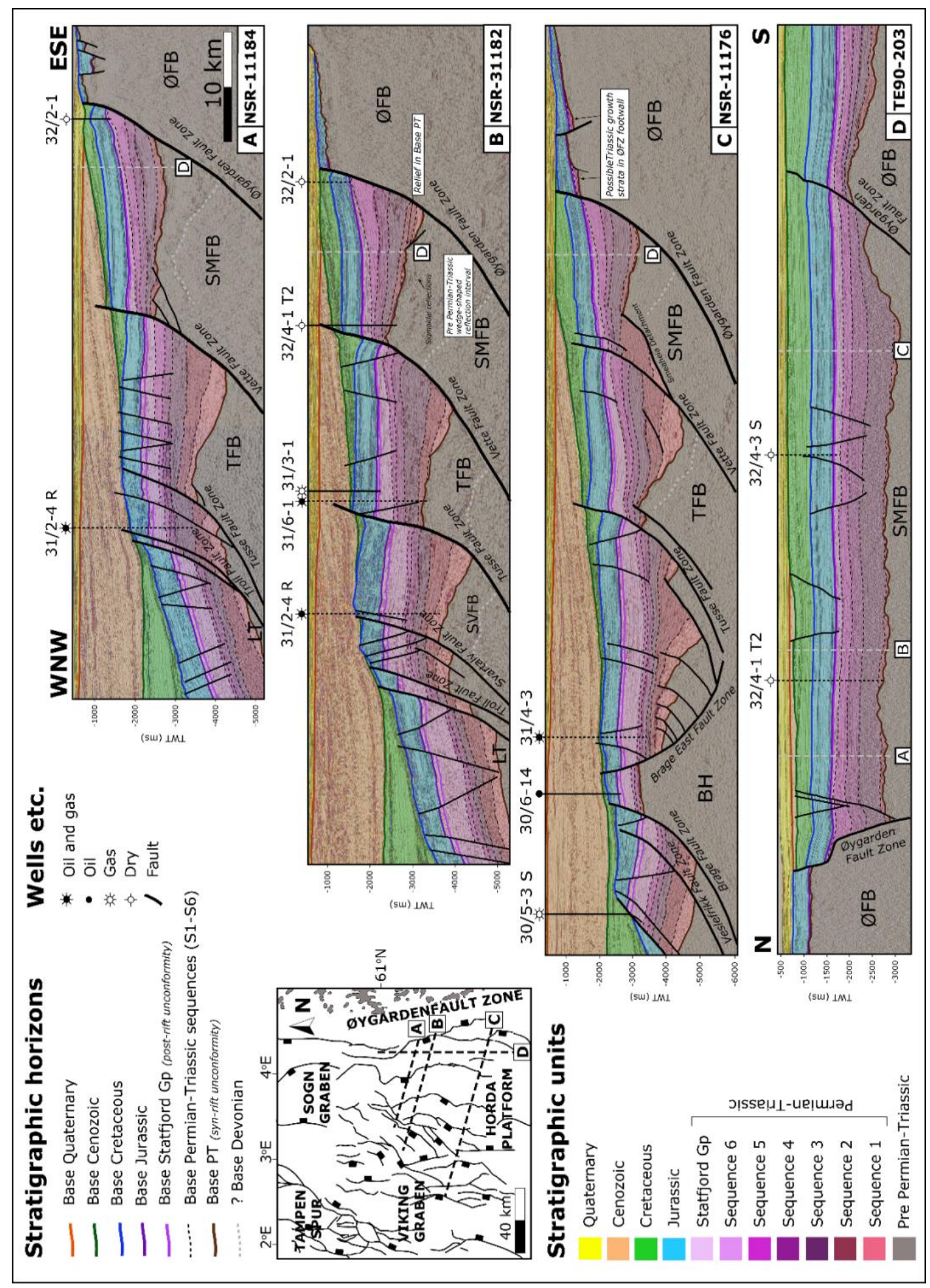

FIGURE 3 Seismic profiles WNW-ENE (A, B, C) and N-S (D) displaying the basin configuration and structural elements along with the defined sequences S1-S6 in the Permian-Triassic stratigraphic interval in the Horda Platform. BH, Brage Horst; LT, Lomre Terrace; SMFB, Smeaheia Fault Block; SVFB, Svartalv Fault Block; TFB, Tusse Fault Block; ØFB, Øygarden Fault Block. The northern North Sea Basin is bordered by the Caledonian hinterland to the east. The basin extends westward to the Shetland Platform and northward to the Sogn Graben. The profiles (A-C) continue westward into the edge of the Horda Platform. The sequences 1-6 are presented in different shades of purple. The interpretations reflect the distribution from N-S and W-E of the different sequences with regards to the fault zones. Indications of structural elements and observations referred to in the text are marked in the figure. Seismic sections are from North Sea Renaissance 2D survey. 


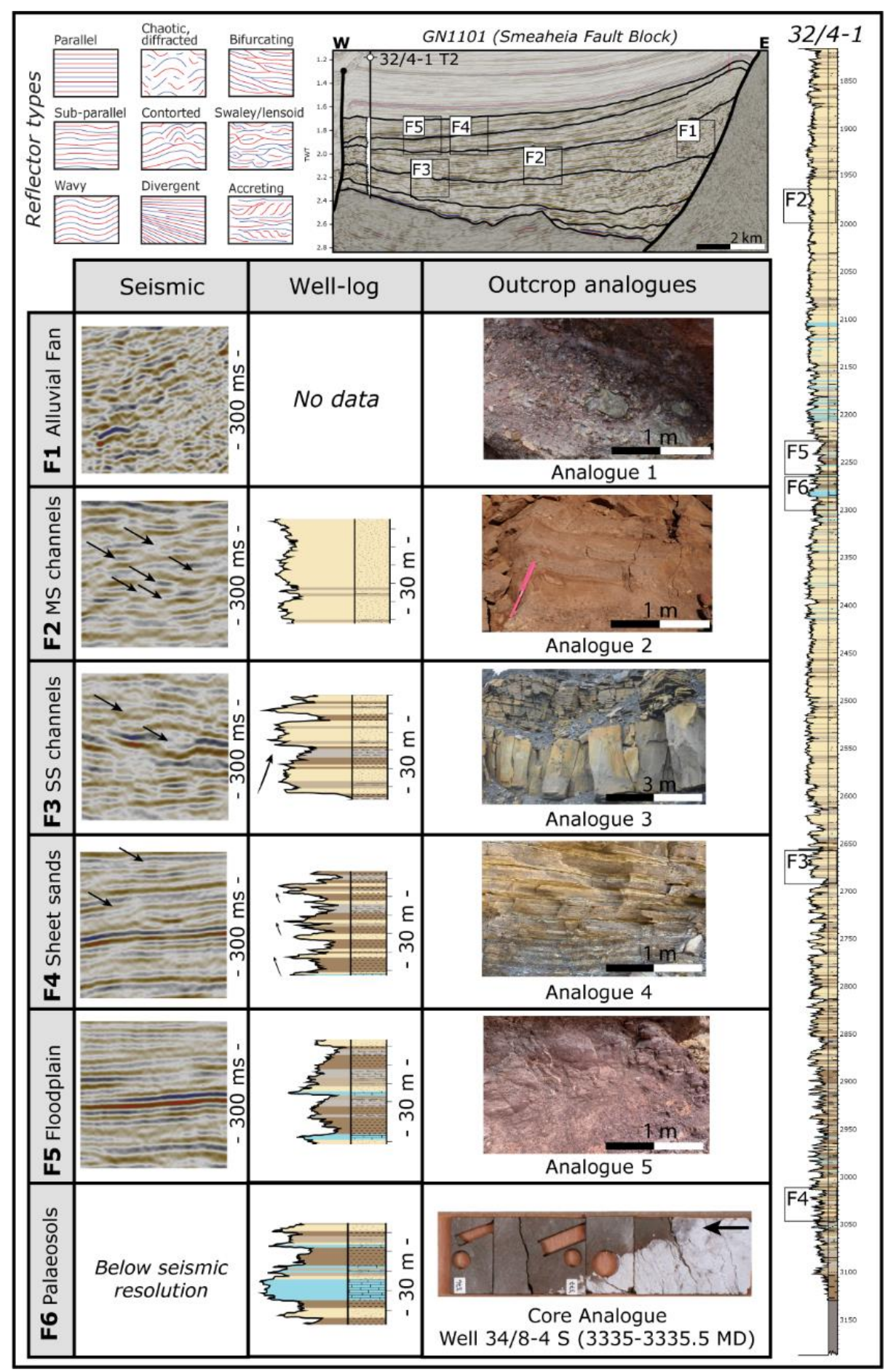

FIGURE 4 Table presenting defined facies' F1-F6 with examples from seismic (GN1101) and well alongside examples from analogue outcrops. Analogue 1: matrix-supported non-graded conglomerate, Middle Carboniferous Odelfjellet Member, Pyramiden Mountain, Svalbard; Analogue 2: trough cross-bedded, stacked, braided channel sandstones, Middle Carboniferous Odellfjellet Member, Pyramiden Mountain, Svalbard. Analogue 3: Single-storey channel sequence, Lower Carboniferous Billefjorden Group, Birger Johnsonfjellet, Svalbard. Analogue 4: Interbedded sheet sandstones, silt and mud, Late Cretaceous Qahlah Formation, Fanja Basin, Oman. Analogue 5: Silty, red floodplain mudstones, Late Cretaceous Qahlah Formation, Fanja Basin, Oman. Core analogue in place of outcrop show a palaeosol horizon in the upper part of a single storey channel unit, Upper Triassic Lunde Formation, well 34/8-4 S, Visund Field, Tampen Spur. Note the scale difference between seismic, well-log and outcrop data. A conceptual presentation of the seismic facies is included in the upper left corner. 


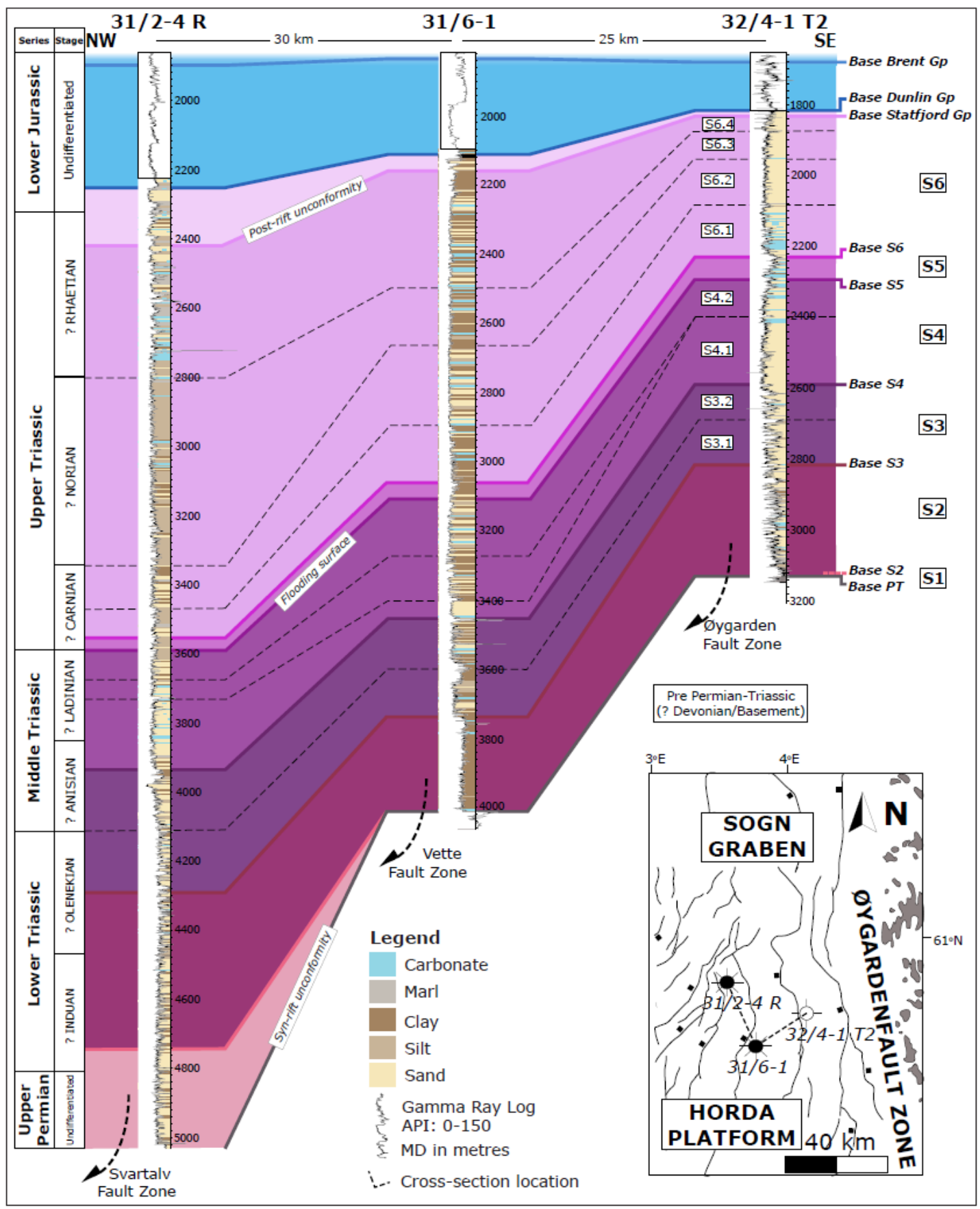

FIGURE 5 Stratigraphic correlation panel between the three wells (32/4-1, 31/6-1, and 31/2-4 R) used in this study. The wells are drilled in the footwall to each of the major fault zones $\emptyset \mathrm{FZ}, \mathrm{VFZ}$ and TFZ and correlated in from west to east. The wells 32/4-1 (ØFB) and 31/6-1 (SMFB) are drilled into basement, while the western well $31 / 2-4 \mathrm{R}$ (TFB) terminates at $5000 \mathrm{~m}$ depth without reaching basement. The Triassic succession thickens from $1300 \mathrm{~m}$ in the ØFB and $1700 \mathrm{~m}$ in the SMFB to $2600 \mathrm{~m}$ in the TFB. S1 is only present in the western well (31/2-4 R), S2 thickens west, while S3 and S4 show similar thicknesses in all wells, and S5 thickens slightly towards east. S6 thickens significantly towards west. shows similar thickness in all three wells, while S3 thickens slightly west. Sub-sequences are correlated between the wells based on lithological trends. Estimated ages to the defined sequences are based on palynological ages by operator in well 31/2-4 R and are lithostratigraphically correlated to the adjacent wells. 


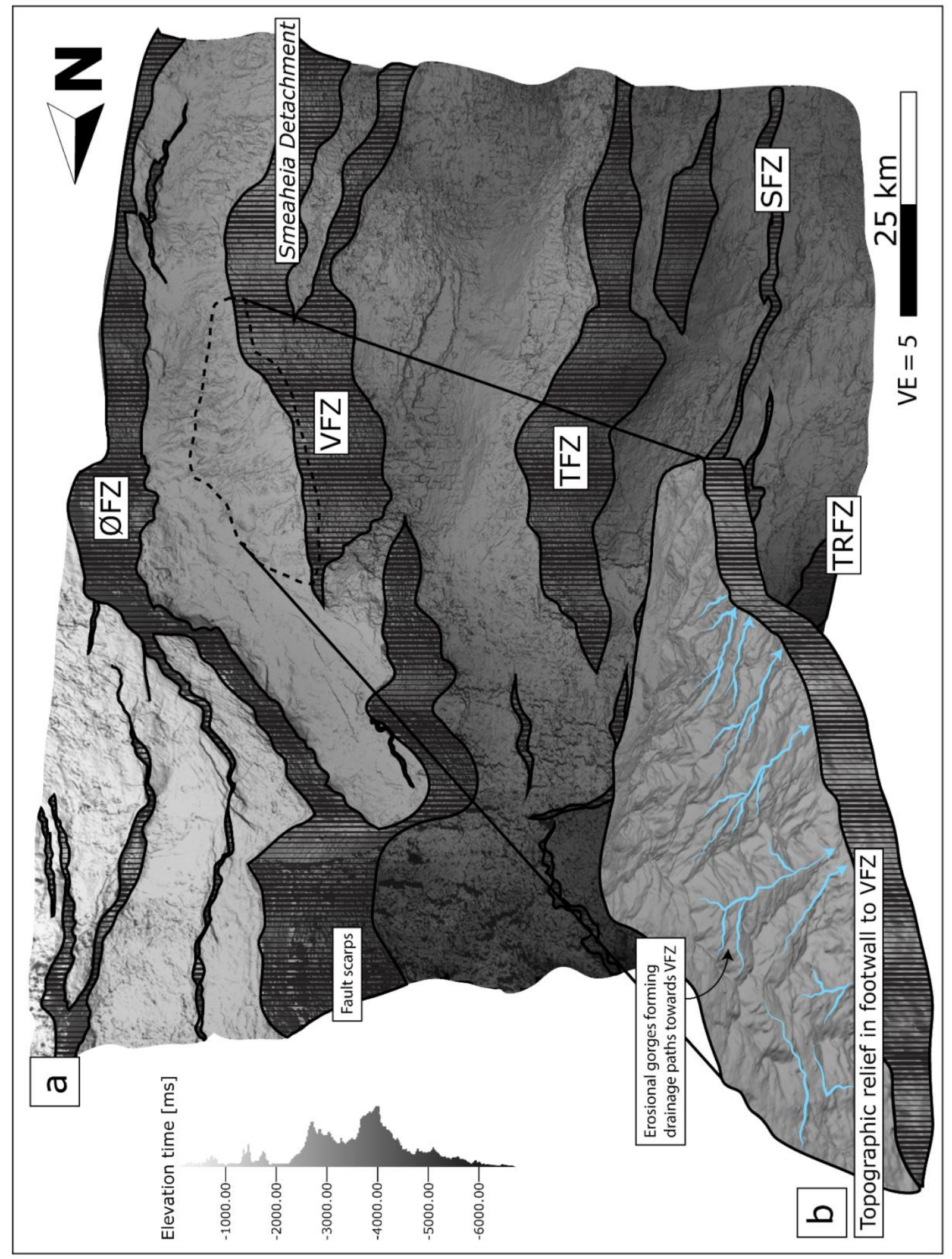

FIGURE 6 a) Surface map generated from the Base PT surface with VE = 5, covering the study area with faults marked in shading. ØFZ = Øygarden fault Zone, VFZ = Vette fault Zone, TFZ =Tusse Fault Zone, SFZ = Svartalv Fault Zone, TRFZ = Troll Fault Zone. b) Zoom-in on the pre-rift topographic relief in the footwall crest to the Vette fault Zone with drainage patterns illustrated in blue. 


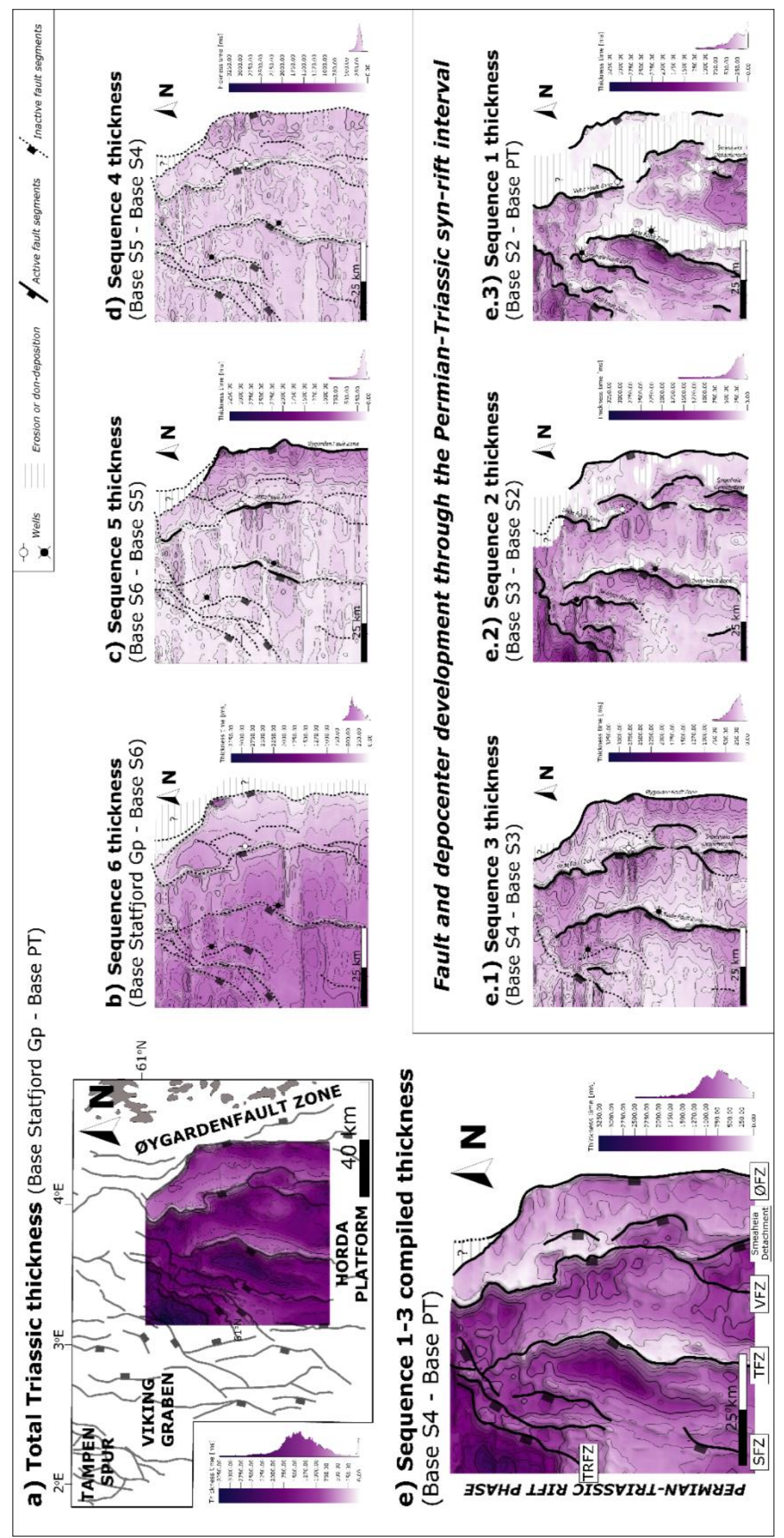

FIGURE 7 Thickness maps between base surfaces for the total Permian-Triassic sequence (a), each of the sequences 1-6 (b-d and e.1-e.3), and S1-3 compiled (e). In the colour bars, white reflects $0.00 \mathrm{~m}$ thickness while a purple scale darkens with increased thickness. 


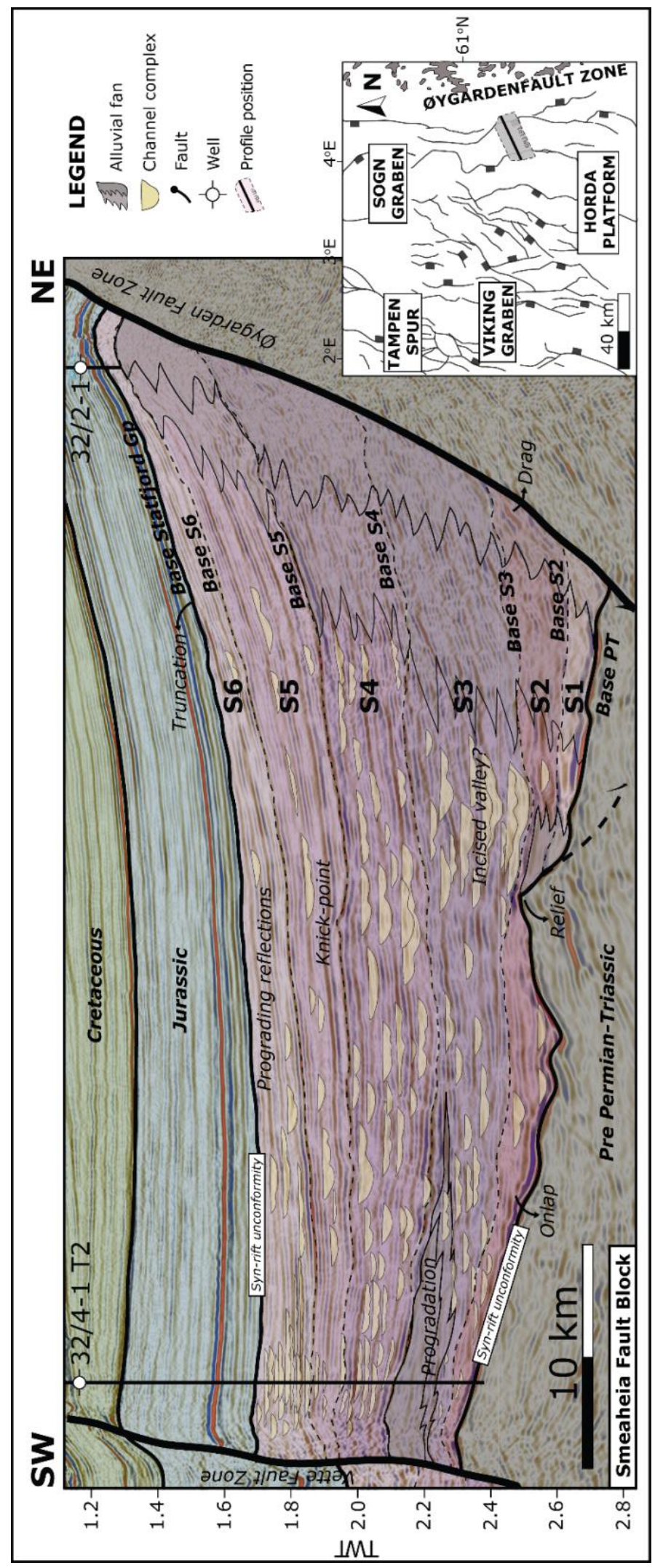

FIGURE 8 Seismic 3D line GN1101 through the Smeaheia Fault Block with structural features, stratigraphic sequence boundaries, and facies interpretations. Note the annotated features discussed in the text (e.g. topographic relief in Base PT surface, onlap relations, progradational features, dragging reflections, truncation). 


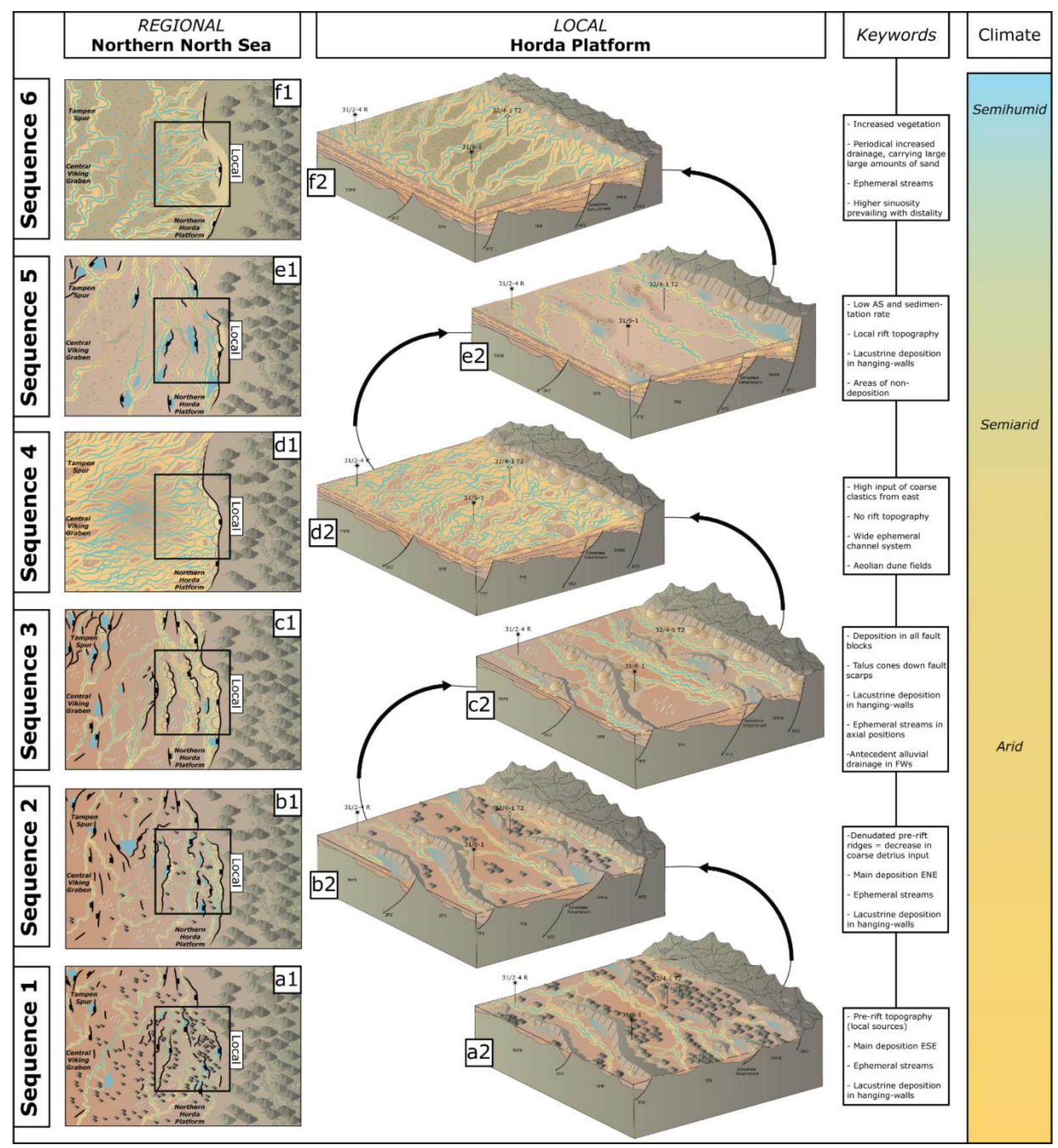

FIGURE 9 Basin development models presented on a regional (northern North Sea) and local (Horda Platform) scale in 3D with structural features and depositional environments, illustration how these change over time. Right-hand bar shows climatic changes over the course of the Triassic. 


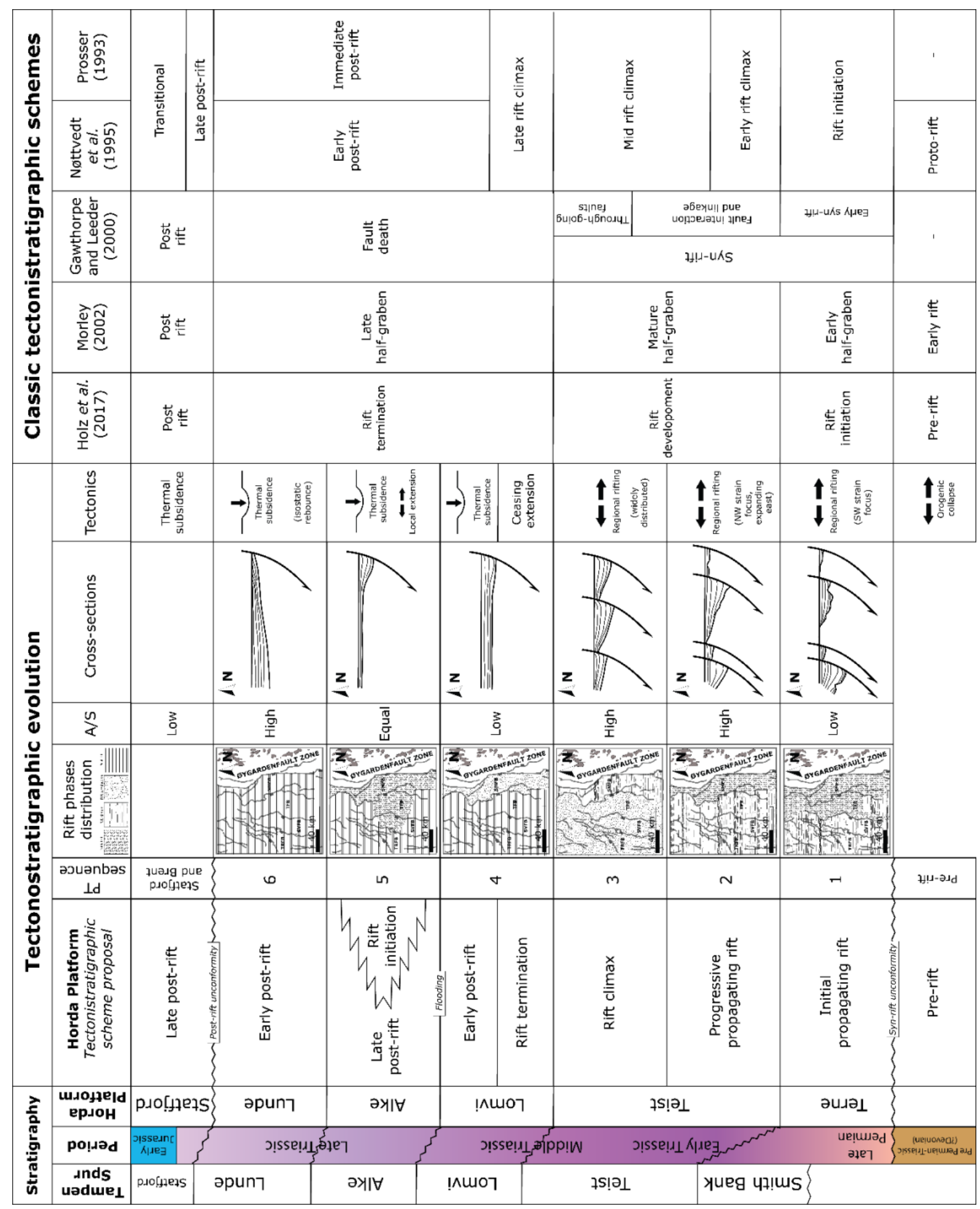

FIGURE 10 Stratigraphic comparison panel. The tectonostratigraphic evolution of the Permian-Triassic succession in the Horda Platform is presented through a sequence-stratigraphic sub-division, rift phase distribution in map view through time, A/S, conceptual presentation of seismic cross-sections, and tectonic stages. These features are compared to classic tectonistratigraphic schemes. A proposal for a stratigraphic application and a chronostratigraphic correlation to the equivalents formations in Tampen Spur are presented. 